San Jose State University

SJSU ScholarWorks

Mineta Transportation Institute Publications

$10-2020$

\title{
Freight Demand Model for Southern California Freeways with Owner-Operator Truck Drivers
}

Joseph J. Kim

California State University, Long Beach

Samuel Dominguez

California State University, Long Beach

Luis Diaz

California State University, Long Beach

Follow this and additional works at: https://scholarworks.sjsu.edu/mti_publications

Part of the Operations and Supply Chain Management Commons, and the Transportation Commons

\section{Recommended Citation}

Joseph J. Kim, Samuel Dominguez, and Luis Diaz. "Freight Demand Model for Southern California Freeways with Owner-Operator Truck Drivers" Mineta Transportation Institute Publications (2020). https://doi.org/10.31979/mti.2020.1931

This Report is brought to you for free and open access by SJSU ScholarWorks. It has been accepted for inclusion in Mineta Transportation Institute Publications by an authorized administrator of SJSU ScholarWorks. For more information, please contact scholarworks@sjsu.edu. 


\section{SJSU Salvosistrat}

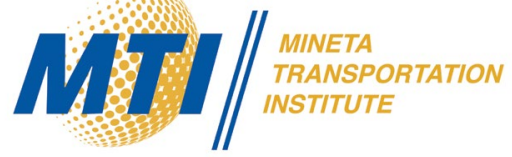

Freight Demand Model for Southern California Freeways with Owner-Operator Truck Drivers

Joseph J. Kim, PhD, PE Samuel Dominguez Luis Diaz

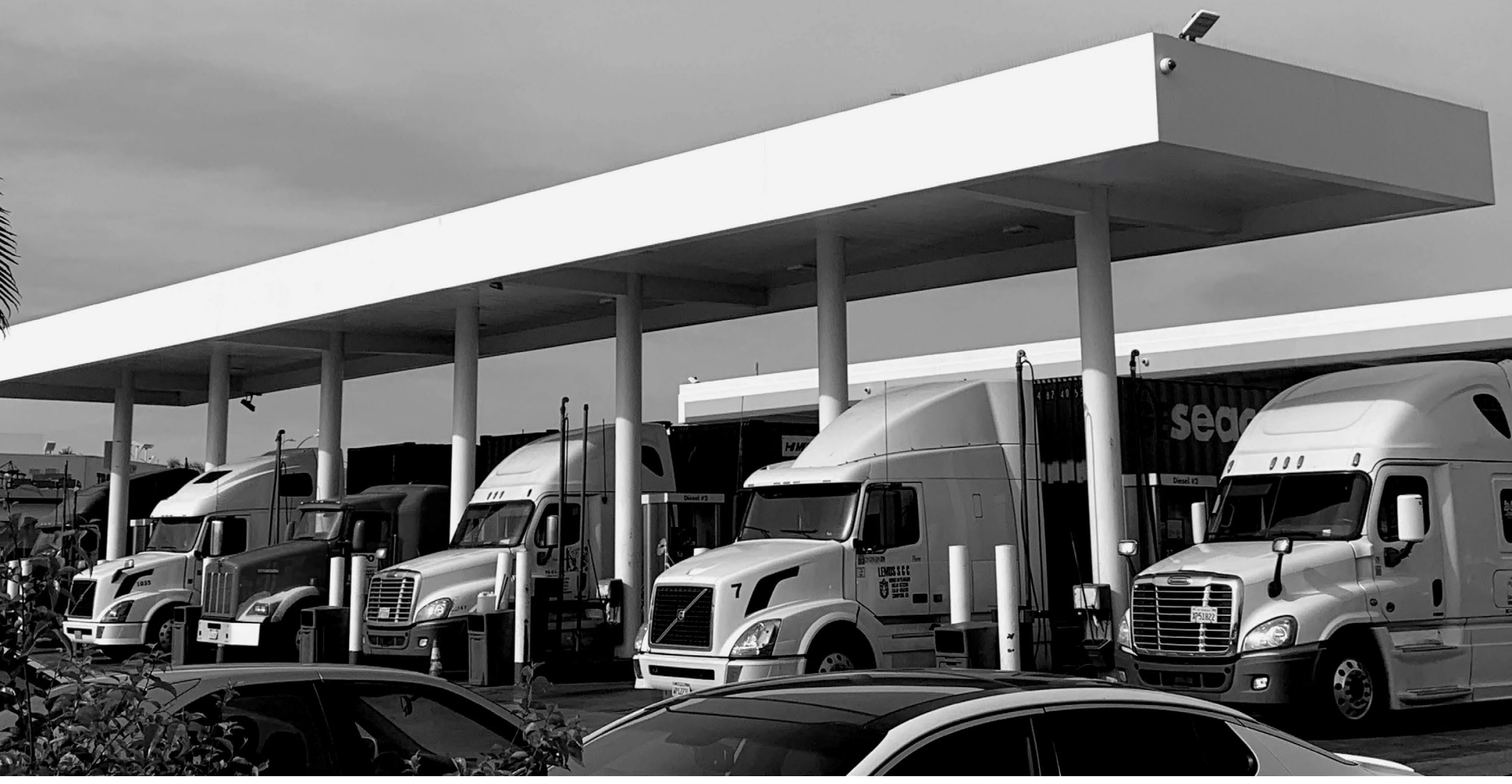




\section{MINETA TRANSPORTATION INSTITUTE}

Founded in 199I, the Mineta Transportation Institute (MTI), an organized research and training unit in partnership with the Lucas College and Graduate School of Business at San José State University (SJSU), increases mobility for all by improving the safety, efficiency, accessibility, and convenience of our nation's transportation system. Through research, education, workforce development, and technology transfer, we help create a connected world. MTI leads the four-university. MTI leads the four-university California State University Transportation Consortium funded by the State of California through Senate Bill I.

MTl's transportation policy work is centered on three primary responsibilities:

\section{Research}

MTI works to provide policy-oriented research for all levels of government and the private sector to foster the development of optimum surface transportation systems. Research areas include: bicycle and pedestrian issues; financing public and private sector transportation improvements; intermodal connectivity and integration; safety and security of transportation systems; sustainability of transportation systems; transportation / land use / environment; and transportation planning and policy development. Certified Research Associates conduct the research. Certification requires an advanced degree, generally a Ph.D., a record of academic publications, and professional references. Research projects culminate in a peer-reviewed publication, available on TransWeb, the MTI website (http://transweb.sjsu.edu).

\section{Education}

The Institute supports education programs for students seeking a career in the development and operation of surface transportation systems. MTI, through San José State University, offers an AACSBaccredited Master of Science in Transportation Management and graduate certificates in Transportation Management, Transportation Security, and High-Speed Rail Management that serve to prepare the nation's transportation managers for the 2 I st century. With the active assistance of the California Department ofTransportation (Caltrans), MTI delivers its classes over a state-of-the-art videoconference network throughout the state of California and via webcasting beyond, allowing working transportation professionals to pursue an advanced degree regardless of their location. To meet the needs of employers seeking a diverse workforce, MTl's education program promotes enrollment to under-represented groups.

\section{Information and Technology Transfer}

MTI utilizes a diverse array of dissemination methods and media to ensure research results reach those responsible for managing change. These methods include publication, seminars, workshops, websites, social media, webinars, and other technology transfer mechanisms. Additionally, MTI promotes the availability of completed research to professional organizations and journals and works to integrate the research findings into the graduate education program.MTl's extensive collection of transportation- related publications is integrated into San José State University's world-class Martin Luther King, Jr. Library.

\section{Disclaimer}

The contents of this report reflect the views of the authors, who are responsible for the facts and accuracy of the information presented herein. This document is disseminated in the interest of information exchange. The report is funded, partially or entirely, by a grant from the State of California. This report does not necessarily reflect the official views or policies of the State of California or the Mineta Transportation Institute, who assume no liability for the contents or use thereof. This report does not constitute a standard specification, design standard, or regulation. 
REPORT 20-34

\title{
FREIGHT DEMAND MODEL FOR SOUTHERN CALIFORNIA FREEWAYS WITH OWNER-OPERATOR TRUCK DRIVERS
}

\author{
Joseph J. Kim, PhD, PE \\ Samuel Dominguez \\ Luis Diaz
}

October 2020

A publication of

Mineta Transportation Institute

Created by Congress in 1991

College of Business

San José State University

San José, CA 95192-0219 


\section{TECHNICAL REPORT DOCUMENTATION PAGE}

1. Report No. 20-34

4. Title and Subtitle

Freight Demand Model for Southern California Freeways with Owner-Operator Truck Drivers

2. Government Accession No.
7. Authors

Joseph J. Kim, PhD, PE, https://orcid.org/0000-0003-2801-3009

Samuel Dominguez

Luis Diaz

9. Performing Organization Name and Address

Mineta Transportation Institute

College of Business

San José State University

San José, CA 95192-0219

12. Sponsoring Agency Name and Address

State of California SB1 2017/2018

Trustees of the California State University

Sponsored Programs Administration

401 Golden Shore, 5th Floor

Long Beach, CA 90802
3. Recipient's Catalog No.

5. Report Date

October 2020

6. Performing Organization Code

8. Performing Organization Report CA-MTI-1931

10. Work Unit No.

11. Contract or Grant No. ZSB12017-SJAUX

13. Type of Report and Period Covered Final Report

14. Sponsoring Agency Code

15. Supplemental Notes

DOI: 10.31979/mti.2020.1931

\section{Abstract}

This study evaluates the demand for truck-only toll lanes on Southern California freeways with owner-operator truck drivers. The study implemented the stated preference survey method to estimate the value placed by drivers on time, reliability, and safety measures using various scenarios geared towards assessing those values. The project team met face-to-face with owneroperator truck drivers near the Ports of Los Angeles and Long Beach to understand the drivers' perspectives regarding truck-only toll lanes on Southern California freeways. A data set containing 31 survey responses is obtained and used for statistical data analysis using analysis of variable (ANOVA) and two sample t-tests. The analysis results showed that $75.27 \%$ of the owneroperator truck drivers responded are willing to pay toll fees when they choose routes. The tolerated average toll fees are $\$ 13.77 /$ $\mathrm{hr}$ and $\$ 12.82 / \mathrm{hr}$ for weekdays and weekends, respectively. The analysis results also showed that owner-operator truck drivers will take truck-only toll lanes when they take the routes used in four comparisons out of six comparisons according to the three measures such as values of time, reliability, and safety, despite sharing a common origin and destination. The highest toll fee per mile on any day that drivers are willing to pay when the main factor being compared is value of time is $\$ 0.31 / \mathrm{mile}$ or $\$ 18.35 / \mathrm{hr}$. The toll fees associated with reliability and safety measures are $\$ 0.30 / \mathrm{mile}$ or $\$ 8.94 / \mathrm{hr}$ and $\$ 0.22 / \mathrm{mile}$ or $\$ 11.01 / \mathrm{hr}$, respectively. These results are meaningful for legislators and transportation agencies as the behaviors and route choice characteristics of owner-operator truck drivers help them better understand the utility and demand for truck-only toll lanes.

\begin{tabular}{|l|l|l|l|}
\hline $\begin{array}{l}\text { 17. Key Words } \\
\begin{array}{l}\text { Truck routes, owner operators, } \\
\text { value of time, reliability, safety }\end{array}\end{array}$ & $\begin{array}{l}\text { 18. Distribution Statement } \\
\text { No restrictions. This document is available to the public through } \\
\text { The National Technical Information Service, Springfield, VA 22161 }\end{array}$ \\
\hline $\begin{array}{l}\text { 19. Security Classif. (of this report) } \\
\text { Unclassified }\end{array}$ & $\begin{array}{l}\text { 20. Security Classif. (of this page) } \\
\text { Unclassified }\end{array}$ & $\begin{array}{c}\text { 21. No. of Pages } \\
46\end{array}$ & 22. Price \\
\hline
\end{tabular}




\title{
Copyright $\odot 2020$ \\ by Mineta Transportation Institute \\ All rights reserved
}

DOI: 10.31979/mti.2020.1931

\author{
Mineta Transportation Institute \\ College of Business \\ San José State University \\ San José, CA 95192-0219 \\ Tel: (408) 924-7560 \\ Fax: (408) 924-7565 \\ Email: mineta-institute@sjsu.edu
}

transweb.sjsu.edu 


\section{ACKNOWLEDGMENTS}

The writers of this report thank the owner-operator truck drivers who participated in the face-to-face survey processes during data collection in the areas of Ports of Long Beach and Los Angeles. The writers also thank Dr. Hamid Rahai, Associate Dean for Research and Graduate Programs of College of Engineering at California State University Long Beach, and Dr. Hilary Nixon, Deputy Executive Director of Mineta Transportation Institute at San José State University, for their kind guidance. The authors thank Editing Press, for editorial services, as well as MTI staff, including Executive Director Karen Philbrick, PhD; Graphic Designer Alverina Eka Weinardy; and Communications and Operations Manager Irma Garcia.

This material is based upon work supported by TRANSPORT-2018/19 under the SB1 grant. Any opinions, findings, and conclusions or recommendations expressed in this material are those of the authors and do not necessarily reflect the views of MTI. 


\section{TABLE OF CONTENTS}

$\begin{array}{lr}\text { Executive Summary } & 1\end{array}$

$\begin{array}{lc}\text { I. Introduction } & 3\end{array}$

$\begin{array}{ll}\text { II. Literature Review } & 5\end{array}$

$\begin{array}{ll}\text { III. Research Objectives } & 11\end{array}$

IV. Methodology 12

$\begin{array}{ll}\text { Scenarios Used in Survey } & 15\end{array}$

$\begin{array}{lr}\text { V. Data Collection Process } & 17\end{array}$

$\begin{array}{ll}\text { Study Boundary } & 17\end{array}$

$\begin{array}{ll}\text { Data Collected } & 18\end{array}$

$\begin{array}{ll}\text { VI. Results } & 20\end{array}$

Comparison of Scenarios with Same Origin and Destination 23

Results: Value of Time Scenarios $\quad 24$

Results: Value of Reliability Scenarios $\quad 25$

Results: Safety Scenarios $\quad 26$

$\begin{array}{lr}\text { VII. Conclusions } & 28\end{array}$

$\begin{array}{ll}\text { Appendix A: Stated Preference Survey } & \mathbf{3 0}\end{array}$

$\begin{array}{ll}\text { Abbreviations and Acronyms } & \mathbf{4 0}\end{array}$

$\begin{array}{ll}\text { Bibliography } & 41\end{array}$

$\begin{array}{ll}\text { About the Authors } & 45\end{array}$

$\begin{array}{ll}\text { Peer Review } & 46\end{array}$ 


\section{LIST OF FIGURES}

1. Flowchart for Research Methodology 14

2. Map of Survey Locations of Interest 18

3. Comparison of Respondents' Preference by Scenario 20

4. Comparison of Tolerated Toll Fees by Scenario 22

5. SP Survey Preliminary Questions 30

6. SP Survey Questionnaire for Scenario 1

7. SP Survey Questionnaire for Scenario 2

8. SP Survey Questionnaire for Scenario 3

9. SP Survey Questionnaire for Scenario 4

10. SP Survey Questionnaire for Scenario 5

11. SP Survey Questionnaire for Scenario 6

12. SP Survey Questionnaire for Scenario 7

13. SP Survey Questionnaire for Scenario 8

14. SP Survey Questionnaire for Scenario 9 


\section{LIST OF TABLES}

1. Cases of VOT Estimation by Nation 6

2. Comparison of VOT Estimated Using WR Method 8

3. Comparison of VOT Estimated Using MRS Method 9

4. Comparison of VOT Estimated Using LM Method 9

5. Descriptive Statistics for Tolerated Toll Fees by Scenario 21

6. ANOVA Results on Tolerated Toll Fees for All Nine Scenarios 23

7. Statistical Results for Same Origin and Destination 23

8. Stated Preference Scenarios for VOT 25

9. Results on Estimation for VOT Measures 25

10. Stated Preference Scenarios for VOR 26

11. Results on Estimation for VOR Measures 26

12. Stated Preference Scenarios for Safety Measures 27

13. Results on Estimation for Safety Measures 27

14. Summary of Results on Key Measures $\quad 27$ 


\section{EXECUTIVE SUMMARY}

With Southern California being home to the two busiest and fastest-growing ports in the United States, the freight industry's demand for truck-only toll lanes may be of great interest to transportation agencies as they are concerned with safety, traffic flow, and traffic demand. This study evaluates the demand for truck-only toll lanes in Southern California freeways with owner-operator truck drivers. The study implemented the stated preference survey method to estimate the value placed on time, reliability, and safety measures by owner-operator truck drivers regarding travel routes by using various scenarios geared towards assessing the values. The project team met faceto-face with owner-operator truck drivers to collect data using the structured survey forms and collected complete sets of 31 surveys near the Ports of Los Angeles and Long Beach to understand the drivers' perspectives regarding truck-only toll lanes on Southern California freeways.

The responses showed that owner-operator truck drivers are willing to take the truckonly toll lanes on average of $75.27 \%$ across scenarios having different route choice characteristics. The tolerated toll fees that respondents are willing to pay in average range from $\$ 4.40 / \mathrm{hr}$ to $\$ 30.97 / \mathrm{hr}$ during weekdays, while those fees in average range from $\$ 4.40 / \mathrm{hr}$ to $\$ 30.48 / \mathrm{hr}$ during weekends. The tolerated average toll fees are $\$ 13.77 / \mathrm{hr}$ and $\$ 12.82 / \mathrm{hr}$ for weekdays and weekends, respectively. The highest toll fee per mile on any day that drivers are willing to pay when the main factor being compared is the value of time is $\$ 0.31 / \mathrm{mile}$ or $\$ 18.35 / \mathrm{hr}$. The toll fees for the reliability and safety measures are $\$ 0.30 / \mathrm{mile}$ or $\$ 8.94 / \mathrm{hour}$ and $\$ 0.22 / \mathrm{mile}$ or $\$ 11.01 / \mathrm{hr}$, respectively. The difference in values for all three measures are negligible between weekdays and weekends.

The analysis results showed that owner-operator truck drivers are not willing to pay toll fees for the routes used in two comparisons out of six comparisons despite sharing a common origin and destination. The rational is that they consider tradeoff between VOT and safety measures. However, it is conclusive that owner-operator truck drivers are willing to pay toll fees for the routes used in four comparisons out of six comparisons, despite sharing a common origin and destination. The reason is that the routes considered in the comparisons are more important than measures considered for their route choice decisions. The routes used in four comparisons include the routes from Port of Long Beach to Compton on 1-710, Port of Long Beach to Van Nuys on I-405 with VOT and VOR, Port of Long Beach to Van Nuys on I-405 with VOR and safety measures, and Port of Los Angeles to San Diego on I-5 with no differences among the measures considered. The highest toll fee per mile on any day that drivers are willing to pay when the main factor being compared is the value of time is $\$ 0.31 / \mathrm{mile}$ or $\$ 18.35 / \mathrm{hr}$. The costs for the value of reliability and safety measures are $\$ 0.30 / \mathrm{mile}$ or $\$ 8.94 / \mathrm{hr}$ and $\$ 0.22 / \mathrm{mile}$ or $\$ 11.01 / \mathrm{hr}$, respectively. The difference in values for all three measures is negligible between weekdays and weekends.

When using the value of reliability as a key comparison factor, the results indicate that drivers value reliability similarly to the way they value safety when measured in toll fee per mile. However, when measuring in toll fee per hour, drivers' value for safety is more than twice as great as their value for reliability. Of the three key comparison factors, in 
terms of toll fee per mile, drivers are least willing to pay for toll fees when using the value of time as a key comparison factor and most willing when considering safety measure to be the key comparison factor. In all cases, drivers' subjective value of the safety measure outweighs their value of reliability and time. It was also found that participants deemed it unlikely that their clients would recompense their toll fees. Respondents alleged that most owner-operator truck drivers were already burdened with the increasing costs of regulations and cannot afford toll fees under the current pricing system. These results are meaningful for legislators and transportation agencies as the behaviors and route choice characteristics of owner-operator truck drivers help them better understand the utility and demand for truck-only toll lanes. 


\section{INTRODUCTION}

The U.S. highway system comprises approximately 3.9 million miles of highways, including high-capacity, multilane freeways, urban streets, and unpaved rural roads. The nation's highway system also carries approximately $29 \%$ of all intercity ton-miles of freight, which generates $75 \%$ of intercity freight revenue. Depending on the truck size, ownership, and use, the truck population is diverse and can cause severe traffic congestion. For example, truck transportation from the Ports of Los Angeles and Long Beach is often bottlenecked due to the heavy traffic demands and limited road capacity. Shipper responses to travel cost, reliability of on-time arrival, comfort, convenience, safety, and ownership are important to understand shipper behaviors with respect to these parameters, which will aid in developing appropriate strategies and incentives for better managing shared systems.

More importantly, the economic feasibility study for a truck-only toll lane is useful in determining whether truck-only toll lanes can be built and how much economic worth can be obtained if the consumed resources are invested in other development projects. Therefore, it is vital to evaluate various factors with equal criteria and methods to ensure impartiality. At present, when administering federal aid funds, the Federal Highway Administration requires a feasibility study including benefit-cost analysis, non-monetary but quantifiable considerations, non-quantifiable considerations, and base case and sensitivity analysis.

In conducting the feasibility study, a value of time (VOT) for truck travels is one of the critical factors among various cost and benefit items for the economic feasibility study of a truckonly toll lane. The VOT is defined as a monetary value that travelers are willing to pay to reduce travel time. The estimation methods for VOT vary depending on the researchers. Most of the methods are classified by travel purpose. Some of them are also classified by income, cost function, utility function, and mode choice. Various estimation methods are available in the literature; however, the wage rate (WR) method and the marginal rate of substitution (MRS) have been adopted for the estimation of VOT.

The VOT using the WR method has been calculated in the existing studies with the regular wage rate of drivers for both personal and truck travels. However, the WR method has raised some problems in estimating the VOT because there is a difference between the wage of truck operators and the value of goods being transported. The difference between the value of goods and the wage of truck operators is the basis of estimating the VOT. To overcome the drawbacks of the WR method, several studies have recently started to pay attention to the MRS method. The stated preference (SP) method is a technique that uses individual respondents' statements about their preference in a set of transport options to estimate utility functions.

A route choice preference study used in this research is one of the demand analysis processes which determines the number or percentage of preferences between truck routes indicated by owner-operator truck drivers. The selection of truck routes is significantly complex, depending on factors such as the owner-operator truck driver's income, the availability of transit service, and the relative advantages of each mode in 
terms of travel time, cost, comfort, convenience, and safety. Therefore, owner-operator truck drivers' route choice valuations developed in this research attempt to replicate the relevant characteristics of the truck operators, the transportation system, and the trip itself to obtain a realistic estimate of the number of trips by each mode for each zone. The value placed on travel time of trucks, which constitutes a considerable portion of the benefit items in the economic feasibility study for a truck-only toll lane, needs to be validated by going beyond a typical academic discussion.

This research is implemented based on the Pl's recent Caltrans project that developed a full research design for the subject matter. The project team designs and collects stated preference survey data from truck drivers, specifically those who are owner-operator truck drivers and whose origin is the Port of Long Beach or the Port of Los Angeles, when they are deciding which route to take. The purpose of this SP survey is to evaluate the average value of travel time, value of travel reliability, and value placed on safety measures from a representative sample of owner-operator truck drivers.

The main objective of this research is to implement field surveys using the stated preference method to examine the value of travel time, value of travel reliability, and safety measures of owner-operator truck drivers' travel, and finally to present more comprehensive shipper responses to travel time reliability than those available in existing studies. The findings can be used in assessing the economic feasibility of a truck-only toll lane development associated with truck traffic patterns. Understanding the difference between the value of goods and the wage of truck operators is critical for developing new strategies and incentives for the transportation agencies to better manage the highway systems. 


\section{LITERATURE REVIEW}

The project team has completed a critical literature review and summarized key information to show how the existing studies relate to the project work. Kawamura (2000) performed a comparative analysis for choosing toll-free roads and toll roads considering different characteristics such as the business type and the shipment size. Small (2005) studied different approaches for computing VOT, while Li et al. (2010) discussed a hypothetical bias choice and willingness to pay. The findings resulted in a significant impact in the real market. Another study surveyed route choice characteristics using the SP method related to VOT in major U.S. and Canadian highways in Texas, Indiana, and Ontario (Sun et al. 2013). The study found that there are significant differences in the route choice decision-making process in the various driver segments, and that these decisions are affected by multiple factors beyond travel time and cost.

Table 1 tabulates a summary of related studies for estimating VOT and VOR by nation. Small et al. (1999) presented the valuation of travel-time savings and predictability in congested conditions for highway user-cost estimation. Lam et al. (2001) conducted a value pricing experiment on actual behavior of commuters on State Route 91 in Orange County, California which helped calculate the value of time and reliability. Zamparini and Reggiani (2007) conducted a meta-analysis of empirical studies and found the value of travel time savings from a theoretical and empirical viewpoint.

Brownstone and Small (2005) conducted two road pricing demonstrations in Southern California in order to calculate the value of time and reliability. Carrion and Levinson (2013) conducted research with a GPS-based experimental design that shows drivers' route choices. Kawamura (2003) investigated commercial vehicles in urban areas and their implications for perceived benefits created by congestion pricing objects helped estimate the value of time. Small et al. (2005) conducted a study investigating the distribution of motorists' preferences and found the travel time and reliability. Miao (2014) carried out an investigation where the marginal monetary benefits and costs were examined for reduced and prolonged freight transportation time on highways, and that study revealed many aspects of the value of time in the trucking industry.

Tilahum and Levinson (2007) compared the value of time between people who arrived at their destination as planned and those who arrived late. Sheikh et al. (2014) examined travelers' willingness to pay for the I-85 express lanes in Atlanta, Georgia. Ehreke et al. (2015) relied on the German Federal Ministry of Transport and Digital Infrastructure reliability study in finding the value of time. The German study collected data through a stated preference method. Alvarez et al. (2007) conducted a study using the stated preference method to evaluate the transport policies and investment decisions. The study found the connection between transport policies in a parallel road network and value of time. Asensio and Matas (2008) evaluated commuters' valuation of travel time variability.

Kawamura (2000) found that for-hire trucks tend to place greater value on time than private trucks. In addition, the results indicated that companies that pay drivers an hourly rate tended to have a higher value of time than companies that paid drivers in commission. This study used the stated preference method to determine the value of time in a given 
traffic context characterized by a parallel road network. The results indicated that the value of time was higher than usual in Spanish-speaking drivers demonstrated a trend of project evaluation. In addition, two cases were developed to illustrate the relevance of the value of time, where the first related pricing policies of a motorway competing with a trunk road and the second established the minimum amount of traffic that justified the replacement of a single carriageway by a dual carriageway. Also using the stated preference method, Asensio and Matas (2008) found that respondents value travel time variability 2.4 times more (on average) than travel time savings. It was also found that the time at which work starts has significant effects on the value of travel time variability.

\section{Table 1. Cases of VOT Estimation by Nation}

\begin{tabular}{|c|c|c|c|c|c|}
\hline Nation & Reference & Method & Data/Year & Variable & $\begin{array}{l}\text { VOT (USD/hr unless } \\
\text { otherwise stated) }\end{array}$ \\
\hline \multirow[t]{15}{*}{ USA } & $\begin{array}{l}\text { Kawamura } \\
(2000)\end{array}$ & MRS & $\begin{array}{l}\text { SP } \\
1998 / 99\end{array}$ & $\begin{array}{l}\text { Transport time, } \\
\text { toll }\end{array}$ & $\$ 23.40-26.80$ \\
\hline & $\begin{array}{l}\text { Carrion and } \\
\text { Levinson } \\
(2013)\end{array}$ & MRS & 2012 & Travel time, toll cost & $\$ 7.30-7.92$ \\
\hline & $\begin{array}{l}\text { Brownstone } \\
\text { and Small } \\
(2005)\end{array}$ & MRS & RP 2005 & Traveler, toll, travel time & $\$ 20.00-40.00$ \\
\hline & $\begin{array}{l}\text { Lam and } \\
\text { Small (2001) }\end{array}$ & WR & $\begin{array}{l}\text { Loop data } \\
2001\end{array}$ & Travel time, time of day & $\$ 22.87$ \\
\hline & $\begin{array}{l}\text { Liu et al. } \\
\text { (2004) }\end{array}$ & $\begin{array}{l}\mathrm{LM} \\
\text { (mixed) } \\
\text { (MRS) }\end{array}$ & $\begin{array}{l}\text { Loop data } \\
2001\end{array}$ & Travel time, toll, distance & $\$ 12.81$ \\
\hline & $\begin{array}{l}\text { Liu et al. } \\
(2007)\end{array}$ & $\begin{array}{l}\mathrm{LM} \\
\text { (mixed) } \\
\text { (MRS) }\end{array}$ & $\begin{array}{l}\text { Loop data } \\
2001\end{array}$ & $\begin{array}{l}\text { Traveler choice, travel } \\
\text { time }\end{array}$ & $\$ 6.82-27.66$ \\
\hline & Ghosh (2001) & LM & SP/RP 2001 & Distance, toll, travel time & $\begin{array}{l}\$ 20.27 \\
\text { (varies with type data) }\end{array}$ \\
\hline & Small (2005) & MRS & RP/SP 2005 & Travel time, toll & $\begin{array}{l}\text { RP: } \$ 21.46 \\
\text { SP: } \$ 11.92\end{array}$ \\
\hline & Krause (2012) & $\begin{array}{l}\text { VOT cap } \\
\text { procedure } \\
\text { (new method) }\end{array}$ & $\begin{array}{l}\text { GPS } \\
\text { longitudinal } \\
2012\end{array}$ & $\begin{array}{l}\text { Cost of trip, duration, route } \\
\text { choice }\end{array}$ & $\$ 8.34$ \\
\hline & $\begin{array}{l}\text { Cirillo and } \\
\text { Axhausen } \\
\text { (2006) }\end{array}$ & LM (mixed) & SP 2006 & $\begin{array}{l}\text { Travel time, travel length, } \\
\text { mode of travel }\end{array}$ & $\$ 12.00$ \\
\hline & Hossan (2016) & $\begin{array}{l}\text { Logit model } \\
\text { (mixed) }\end{array}$ & SP 2016 & $\begin{array}{l}\text { Out of pocket monetary } \\
\text { cost, trip length, travel } \\
\text { time }\end{array}$ & $\$ 10.68$ \\
\hline & Miao (2014) & MRS & SP 2013 & & $\$ 54.98$ \\
\hline & FHWA (2002) & & 2005 & $\begin{array}{l}\text { Unexpected delays, } \\
\text { shipment }\end{array}$ & $\$ 25-200$ \\
\hline & $\begin{array}{l}\text { Kawamura } \\
(2000)\end{array}$ & Logit model & 1999 & $\begin{array}{l}\text { Shipment size, business } \\
\text { type }\end{array}$ & $\$ 23.4$ \\
\hline & $\begin{array}{l}\text { Calfee and } \\
\text { Winston } \\
\text { (1998) }\end{array}$ & Logit model & SP 1998 & $\begin{array}{l}\text { Transport time, } \\
\text { toll }\end{array}$ & $\$ 3.88$ \\
\hline
\end{tabular}




\begin{tabular}{|c|c|c|c|c|c|}
\hline Nation & Reference & Method & Data/Year & Variable & $\begin{array}{l}\text { VOT (USD/hr unless } \\
\text { otherwise stated) }\end{array}$ \\
\hline & $\begin{array}{l}\text { Tilahum and } \\
\text { Levinson } \\
\text { (2007) }\end{array}$ & MRS & SP 2006 & Toll, departures, delays & $\$ 9.54-25.43$ \\
\hline \multirow[t]{7}{*}{ USA } & $\begin{array}{l}\text { Levinson and } \\
\text { Sunalkoski } \\
\text { (2003) }\end{array}$ & Tobit model & SP 2003 & Truckload, toll & $\$ 49.42$ \\
\hline & Wang (2014) & LM & GPS 2014 & $\begin{array}{l}\text { Travel time, toll rates, } \\
\text { reliability }\end{array}$ & $\begin{array}{l}\text { Peak: } \$ 25.15 \\
\text { Off peak: } \$ 19.44\end{array}$ \\
\hline & $\begin{array}{l}\text { Zamparini } \\
\text { and Reggiani } \\
(2007)\end{array}$ & WR & 2007 & & $\$ 23.29$ \\
\hline & $\begin{array}{l}\text { Sheikh et al. } \\
(2014)\end{array}$ & MRS & SP 2014 & Travel time, toll & $\$ 36.00$ \\
\hline & $\begin{array}{l}\text { Georgia SRTA } \\
(2006)\end{array}$ & & SP 2006 & & $\$ 21$ \\
\hline & Wolff (2014) & $\begin{array}{l}\text { Analyze } \\
\text { driver }\end{array}$ & 2005-2008 & $\begin{array}{l}\text { Driving speed, gasoline } \\
\text { price }\end{array}$ & $\$ 11.52$ \\
\hline & ODOT (2004) & WR & $\begin{array}{l}\text { Average } \\
\text { wage, } \\
\text { Fringe cost } \\
2003\end{array}$ & & $\begin{array}{l}\text { Light truck: } \$ 18.92 \\
\text { Heavy truck: } \$ 25.49\end{array}$ \\
\hline \multirow[t]{2}{*}{ Australia } & Li et al. (2010) & $\begin{array}{l}\text { Scheduling } \\
\text { model }\end{array}$ & SP/RP 2010 & Tolls, delays, travel time & $\$ 30.04$ \\
\hline & $\begin{array}{l}\text { Puckett et al. } \\
\text { (2007) }\end{array}$ & LM & SP 2007 & & $\$ 31.87-63.75$ \\
\hline \multirow[t]{2}{*}{ France } & $\begin{array}{l}\text { de Jong et al. } \\
(2001)\end{array}$ & MRS & $\begin{array}{l}\text { SP/RP } \\
1999 / 2000\end{array}$ & $\begin{array}{l}\text { Transport cost, transport } \\
\text { time, probability of } \\
\text { delay, } \\
\text { frequency of } \\
\text { shipment, etc. }\end{array}$ & $\begin{array}{l}\text { Hire and reward: } \\
\$ 29.00-60.00 \mathrm{FF} \\
(\$ 4.92-10.18)\end{array}$ \\
\hline & $\begin{array}{l}\text { Meunier and } \\
\text { Quinet (2015) }\end{array}$ & & 2010 & & $\begin{array}{l}32.7 \text { euro/hr } \\
(\$ 36.50 \text { USD/hr) }\end{array}$ \\
\hline \multirow[t]{2}{*}{ Germany } & $\begin{array}{l}\text { F.B.T.C. } \\
\text { (1999) }\end{array}$ & MRS & $\begin{array}{l}\text { SP } \\
1999\end{array}$ & $\begin{array}{l}\text { Transport cost, transport } \\
\text { time }\end{array}$ & $\$ 21$ USD/hr \\
\hline & $\begin{array}{l}\text { Ehreke et al. } \\
(2015)\end{array}$ & MRS & SP 2015 & Distance, travel time & $\begin{array}{l}8.38 \text { euro/hr } \\
(\$ 10.44 \mathrm{USD} / \mathrm{hr})\end{array}$ \\
\hline Japan & KOTI (1999) & WR & $\begin{array}{l}\text { Average } \\
\text { wage, } \\
\text { fringe cost } \\
1996\end{array}$ & & $\begin{array}{l}\text { Small truck: } 90 \text { yen/min } \\
\text { ( } \$ 48.60 \text { USD/hr) } \\
\text { Large truck: } 101 \text { yen/min } \\
\text { ( } \$ 54.60 \text { USD } / \mathrm{hr} \text { ) }\end{array}$ \\
\hline
\end{tabular}




\begin{tabular}{|c|c|c|c|c|c|}
\hline Nation & Reference & Method & Data/Year & Variable & $\begin{array}{l}\text { VOT (USD/hr unless } \\
\text { otherwise stated) }\end{array}$ \\
\hline \multirow[t]{2}{*}{ Spain } & $\begin{array}{l}\text { Alvarez et al. } \\
(2007)\end{array}$ & MRS & SP 2007 & & $\begin{array}{l}\text { Passenger vehicle: } \\
31.74 \text { euro/hr } \\
\text { ( } \$ 35.43 \text { USD/hr) } \\
\text { Freight vehicles: } 64.10 \\
\text { euro/hr } \\
\text { (\$71.54 USD/hr) }\end{array}$ \\
\hline & $\begin{array}{l}\text { Asensio and } \\
\text { Matas (2008) }\end{array}$ & MRS & SP 2008 & Travel time, travel cost & $\begin{array}{l}14.10 \text { euro/hr } \\
(\$ 15.74 \text { USD/hr) }\end{array}$ \\
\hline Sweden & Lei (2011) & Logit model & 2011 & Travel time, distance, toll & $\begin{array}{l}\text { Work trips: } \\
176 \text { SEK/hr } \\
\text { (\$18.54 USD/hr) } \\
\text { Other trips: } \\
184 \text { SEK/hr } \\
\text { (\$19.39 USD/hr) }\end{array}$ \\
\hline \multirow[t]{2}{*}{ Netherlands } & $\begin{array}{l}\text { de Jong } \\
\text { (2007) }\end{array}$ & MRS & SP/RP 2010 & $\begin{array}{l}\text { Transport cost, cargo } \\
\text { component }\end{array}$ & $\begin{array}{l}\text { Container 2-40t truck: } \\
59 \text { euro/hr } \\
\text { (\$65.85 USD/hour) } \\
\text { Non-container: } \\
(2-15 \mathrm{t} \text { truck) } \\
23 \text { euro/hr } \\
\text { ( } \$ 25.67 \mathrm{USD} / \mathrm{hr}) \\
(2-40 \mathrm{t} \text { truck) } \\
44 \text { euro/hr } \\
(\$ 49.11 \text { USD/hr) }\end{array}$ \\
\hline & $\begin{array}{l}\text { Kouwenhoven } \\
\text { et al. (2014) }\end{array}$ & $\begin{array}{l}\text { Latent class } \\
\text { models }\end{array}$ & SP 2011 & $\begin{array}{l}\text { Cost, travel time, travel } \\
\text { time variability }\end{array}$ & $\begin{array}{l}\text { Commute: } \\
9.25 \text { euro/hr } \\
\text { (\$10.32 USD/hr) } \\
\text { Business } \\
26.25 \text { euro/hr } \\
\text { (\$29.30 USD/hr) } \\
\text { All purpose: } \\
9.00 \text { euro/hr } \\
(\$ 10.05 \text { USD/hr) }\end{array}$ \\
\hline
\end{tabular}

Table 1 is then further broken down into three tables based on the wage rate (WR), marginal rate of substitution (MRS), and logit model (LM) methods. Tables 2, 3, and 4 show the comparisons of VOT estimated using the WR, MRS, and LM method, respectively.

\section{Table 2. Comparison of VOT Estimated Using WR Method}

\begin{tabular}{llll}
\hline \multirow{2}{*}{ Nation } & \multicolumn{3}{c}{ WR Method (1995 USD/hr) } \\
\cline { 2 - 4 } & Reference & Range & Average \\
\hline USA & FHWA (2002) & $\$ 17.84-25.49$ & $\$ 22.43$ \\
& $\begin{array}{l}\text { Lam et al. (2001) } \\
\text { Zampirini and Reggiani (2007) } \\
\text { ODOT (2004) }\end{array}$ & & \\
South Korea & KDI (2004) & & \\
Japan & KOTI (1999) & $\$ 48.60-64.60$ & $\$ 12.83$ \\
\hline
\end{tabular}


Table 3. Comparison of VOT Estimated Using MRS Method

\begin{tabular}{llll}
\hline \multirow{2}{*}{ Nation } & \multicolumn{3}{c}{ MRS Method (1995 USD/hr) } \\
\cline { 2 - 4 } USA & Reference & Range & Average \\
\hline & $\begin{array}{l}\text { Kawamura (2000) } \\
\text { Small et al. (1999) } \\
\text { Smalkoski and Levinson (2005) }\end{array}$ & & $\$ 26.84$ \\
Carrion and Levinson (2013) & & \\
& $\begin{array}{l}\text { Brownstone and Small (2005) } \\
\text { Small (2005) } \\
\text { Miao (2014) } \\
\text { Tilahum and Levinson (2007) } \\
\text { Choi (2002) }\end{array}$ & & \\
Choi (2004) & & \\
Ehreke et al. (2015) & $\$ 15.76-29.02$ & $\$ 20.63$ \\
Germany & $\begin{array}{l}\text { F.B.T.C. (1999) } \\
\text { Alvarez et al. (2017) } \\
\text { Asensio and Matas (2008) }\end{array}$ & $\$ 10.44-21$ & $\$ 15.72$ \\
Netherlands & de Jong et al. (2001) & $\$ 15.74-71.54$ & $\$ 40.90$ \\
\hline
\end{tabular}

Table 4. Comparison of VOT Estimated Using LM Method

\begin{tabular}{llll}
\hline \multirow{2}{*}{ Nation } & \multicolumn{3}{c}{ LM Method } \\
\cline { 2 - 4 } & Reference & Range & Average \\
\hline & Liu (2004) & & \\
& Liu (2007) & & \\
& Ghosh (2001) & & \\
USA & Hossan (2016) & $\$ 15.32$ \\
& Calfee and Winston (1998) & $\$ 3.88-27.66$ & \\
& Wang (2014) & & \\
& Cirillo and Axhausen (2006) & & \\
Australia & Ghosh (2001) & & $\$ 47.81$ \\
Sweden & Puckett et al. (2007) & $\$ 31.87-63.75$ & $\$ 18.97$ \\
\hline
\end{tabular}

The evaluation results from the Pl's previous Caltrans project were confirmed with key factors that affect the route choice characteristics of owner-operator truck drivers in Southern California freeways by the review of the existing studies. Unlike truck drivers who work for a company, owner-operator truck drivers need to make decisions when considering the best possible route for a trip-since they have the liberty of choosing their own route, and their value of time is dependent on numerous factors, rather than being dependent on their hourly wage. The most significant criterion is the route characteristics, as well as the alternatives under the route characteristics: namely, travel time and reliability of on-time arrival characteristics. The importance of this measure is not surprising, because the variables of travel time and reliability of on-time arrival are the two variables that are most often considered in related studies. Another factor that plays a significant role within this criterion is safety, which is consistent with expectations. The other factor is travel cost: reasonably so, as it is directly related to travel time. It is notable that the factor of scheduled delivery is so high in relation to all other alternatives, as this variable is only considered by a few related studies, although it is reasonable for the drivers to adhere to their own set schedule. Additionally, the other alternatives 
within this criterion (behind schedule and congestion hotspot) would play a minor role, as these are related to whether a scheduled delivery time will be met. One explanation for these findings is that none of the related studies were specifically conducted in Southern California highway systems focusing on owner-operator truck drivers. Another explanation is that truck drivers believe that these identified variables are important. Their opinions might suggest that further data collection is necessary to obtain a more accurate representation of the diverse population of drivers, which is the motivation of this research. 


\section{RESEARCH OBJECTIVES}

The goal of this research project is to better understand the behaviors of owner-operator truck drivers to enhance decision-making regarding their route choice characteristics. The main objectives of this research, achieved by implementing the stated preference survey method by meeting face-to-face with owner-operator truck drivers in the field, are to estimate the values the drivers place on time, reliability, and safety measures of their travel routes, and to provide transportation agencies with meaningful data on these drivers' behaviors and patterns. The findings will help obtain a better understanding of the contemporary issues and demands. The research outcome is to produce high-quality field data and discuss the corresponding analytical results on truck travel patterns, which will be of interest to transportation agencies by virtue of being applicable to estimating the utility of a truck-only toll lane. 


\section{METHODOLOGY}

The survey was conducted using the stated preference survey form with owner-operator truck drivers. The project team met face-to-face with the participants who were asked to answer the questions given on the survey form. The survey form includes basic information such as owner-operator truck drivers, the number of years spent driving semi-trucks, and the number of axles they drive. The project team designed the scenarios based on the boundary condition of the project. The starting point of truck operators is either from the Port of LA or Port of LB, and the end points are the designated distribution centers located within the closest distance. The scenarios for the full design were selected from the following list by taking into considerations such as route, distance, toll charge, average speed, reliability, time of day, quantity of passenger cars, and weather conditions. Some of the routes were not chosen because of the frequency of the truck travels. Refer to the Appendix for the entire nine scenarios used in the stated preference survey form.

- Los Angeles Port to Pasadena on I 110

- Long Beach Port to Compton on I 710

- Long Beach Port to Van Nuys on I 1405

- Long Beach Port to Van Nuys on I 1405 with different reliability and toll

- Los Angeles Port to San Diego on I 5

- Los Angeles Port to San Diego on I 5 with different reliability and toll

- Los Angeles Port to Pasadena on I 110 with safety measure

- Long Beach Port to Compton on I 710 with safety and weather measure

- Long Beach Port to Van Nuys on I 405 with safety and time measure

- Long Beach Port to Alhambra on I 710 with delivery time measure

- Los Angeles Port to Gardena on I 110 with truck cargo price measure

- Los Angeles Port to Dana Point on I 5 with truck cargo price measure

- Long Beach Port to Carson on I 710 with truck gas mileage measure

- Long Beach Port to Lake Forest on I 405 with truck gas mileage measure

- Los Angeles Port to Carson on I 110 with truck comfort level measure

- Santa Clarita to San Clemente on I 5 with truck comfort level measure 
Nine scenarios were carefully designed to help understand owner-operator truck drivers' perspectives on truck-only toll lanes for Southern California freeways near the Port of Long Beach and the Port of Los Angeles. Thus, every scenario uses one or more key comparison factors, such as VOT, VOR, or safety measures. Additionally, each scenario contains a truck-only toll lane option and a no-toll option. The scenarios vary in route, distance, toll charge, average speed, reliability, time of day, quantity of passenger cars, and weather conditions. The survey form was approved by the California State University Long Beach's Institutional Research Board (IRB). Figure 1 is a flowchart depicting the research methodology. 


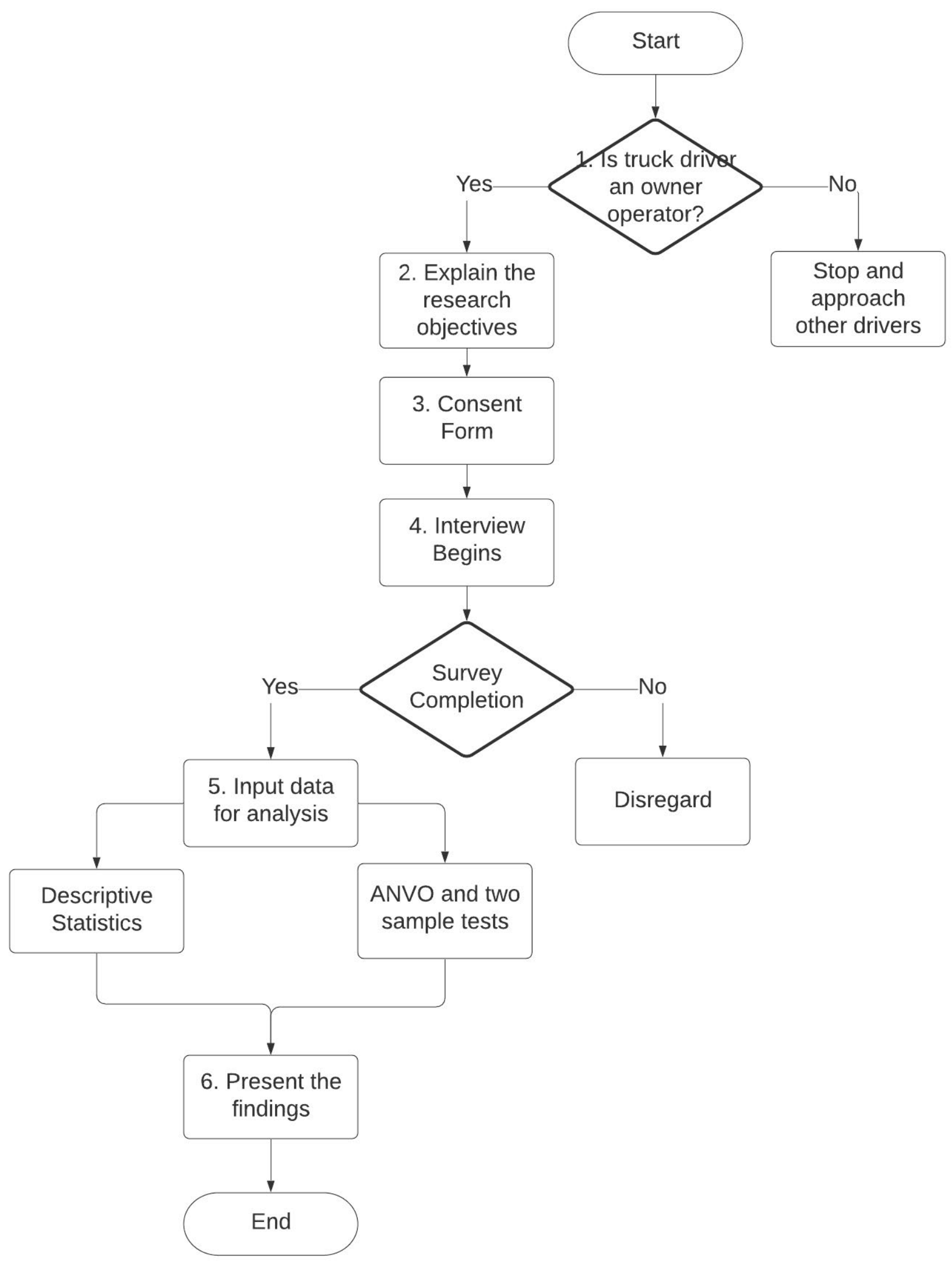

Figure 1. Flowchart for Research Methodology 


\section{SCENARIOS USED IN SURVEY}

\section{Scenario 1}

Scenario 1 describes a 30-mile route on a no-toll lane from the Port of LA to Pasadena on I-110 with an average speed of $30 \mathrm{mph}$, a travel time of 60 minutes, heavy traffic, and using VOT as a key comparison factor. For the same route, scenario 1 describes a $\$ 15$ truck-only toll lane with little to no traffic that reduces travel time to 30 minutes and increases the average speed to $60 \mathrm{mph}$.

\section{Scenario 2}

Scenario 2 describes a 15-mile route on a no-toll lane from Port of Long Beach to Compton on I-710 with an average speed between $15 \mathrm{mph}$ and $60 \mathrm{mph}$, a $50 \%$ chance of a 15-minute travel time, a 50\% chance of a 60 -minute travel time, and using VOR as a key comparison factor. For the same route, scenario 2 describes a $\$ 15$ truck-only toll lane that reduces travel time to a $100 \%$ chance of a $30-$ minute travel time and increases the average speed to $60 \mathrm{mph}$.

\section{Scenario 3}

Scenario 3 describes a 45-mile route on a no-toll lane from Long Beach to Van Nuys on I-405 with an average speed of $15 \mathrm{mph}$, a travel time of 180 minutes, heavy traffic, and using VOT as a key comparison factor. For the same route, scenario 3 describes a $\$ 30$ truck-only toll lane with little to no traffic that reduces travel time to 45 minutes and increases the average speed to $60 \mathrm{mph}$.

\section{Scenario 4}

Scenario 4 describes a 45-mile route on a no-toll lane from Long Beach to Van Nuys on I-405 with an average speed between 15 and $60 \mathrm{mph}$, a $50 \%$ chance of a 45-minute travel time, a $50 \%$ chance of a 180 -minute travel time, and using VOR as a key comparison factor. For the same route, scenario 4 describes a $\$ 15$ truck-only toll lane that reduces travel time to a $100 \%$ chance of a 90 -minute travel time and increases the average speed to $30 \mathrm{mph}$.

\section{Scenario 5}

Scenario 5 describes a 120-mile route on a no-toll lane from Los Angeles to San Diego on I-5 with an average speed of $20 \mathrm{mph}$, a travel time of 360 minutes, heavy traffic, and using VOT as a key comparison factor. For the same route, scenario 5 describes a $\$ 60$ truck-only toll lane with little to no traffic that reduces travel time to 120 minutes and increases the average speed to $60 \mathrm{mph}$. 


\section{Scenario 6}

Scenario 6 describes a 120-mile route on a no-toll lane from Los Angeles to San Diego on I-5 with an average speed between 20 and $60 \mathrm{mph}$, a $50 \%$ chance of a 120-minute travel time, a $50 \%$ chance of a 360 -minute travel time and using VOR as a key comparison factor. For the same route, scenario 6 describes a $\$ 30$ truck-only toll lane that reduces travel time to a $100 \%$ chance of a 240 -minute travel time and increases the average speed to $30 \mathrm{mph}$.

\section{Scenario 7}

Scenario 7 describes a 30-mile route on a no-toll lane from the Port of LA to Pasadena on I-110 with an average speed of $60 \mathrm{mph}$, a travel time of 30 minutes, relatively low safety, little to no traffic, many passenger cars, and using safety as a key comparison factor. For the same route, scenario 7 describes a $\$ 5$ truck-only toll lane with little to no traffic, no passenger cars, and relatively high safety with an unchanged travel time (30 minutes) and an average speed of $60 \mathrm{mph}$.

\section{Scenario 8}

Scenario 8 describes a 15-mile route on a no-toll lane from the from the Port of Long Beach to Compton on I-710 with an average speed of $45 \mathrm{mph}$, a travel time of 20 minutes, heavy rain, relatively low safety, little to no traffic, and using safety and weather as key comparison factors. For the same route, scenario 8 describes a $\$ 5$ truck-only toll lane with little to no traffic, no rain, and relatively high safety with an unchanged travel time (20 minutes) and an average speed of $45 \mathrm{mph}$.

\section{Scenario 9}

Scenario 9 describes a 45-mile route on a no-toll lane during nighttime from Long Beach to Van Nuys on I-405 with an average speed of $45 \mathrm{mph}$, a travel time of 60 minutes, relatively low safety, little to no traffic, and using safety and time of day as key comparison factors. For the same route, scenario 9 describes a $\$ 5$ truck-only toll lane during the day with little to no traffic, and relatively high safety with an unchanged travel time (60 minutes) and an average speed of $45 \mathrm{mph}$. 


\section{DATA COLLECTION PROCESS}

\section{STUDY BOUNDARY}

The research team selected the research boundary within Southern California's network of toll-free and toll roads. Toll roads includes the $\mathrm{I}-10$ and $\mathrm{I}-110$ express lanes owned and operated by Metro, the 91 express lanes owned and operated by the Orange County Transportation Authority, the 241, 261, 133, and 73 toll roads operated by the Transportation Corridor Agencies, and the I-15 express lanes and SR-125 in San Diego County (Southern California Toll Roads 2014). Per a Caltrans report, the 2010 data are based on a count of 1,368 trucks/day and 44,000 vehicles/day, or $3.1 \%$ trucks. Over two-thirds of these trucks are small trucks with two or three axles. Similar percentages can be calculated for locations farther south, such as the segments between SR 60 and I-10 (5.0\%), north of I-5 (7.6\%), north of I-405 (14.3\%), and at the beginning of I-710 near the Port of Long Beach (26.4\%). Truck count data, while useful, do not reveal anything about origins and destinations (where trucks are coming from and going to), which is the focal point of this research project.

In this research, the project team identified the origins and destinations of truck transportation. Over $85 \%$ of truck trips in LA County stay completely within the six-county SCAG region and do not involve goods from the San Pedro ports. For example, these truck trips are transporting goods from suppliers to manufacturers or from regional distribution centers to local stores. Only approximately $6 \%$ of truck trips in LA County are passing through on their way from an origin to a destination outside the region, such as agricultural products being transported from the Central Valley to the southwest. Fewer than $8 \%$ of truck trips in LA County start or end at the San Pedro ports or are carrying goods directly transferred from the ports (SCAG 2012 RTP/SCS, Goods Movement).

\section{DATA COLLECTION PROCESS}

The data collection process involved a number of designed stages, including the survey location selection, participant recruitment, and survey process. Due to the nature of this research being dependent only on owner-operator truck drivers' responses, the selection of the survey location was a critical stage in the data collection process because it had to satisfy a number of survey criteria. Figure 2 shows the map of survey locations of interest.

A criterion for survey location selection was devised in order to accommodate the lifestyle of working owner-operator truck drivers. This criterion required that the location satisfy the following conditions. First, the location needed to be a place with a high population density of owner-operator truck drivers who work in the Southern California region, are familiar with the routes mentioned in the survey, and are willing participants. Second, the location needed to be a place or area where a survey activity would be appropriate in terms of safety, accessibility, and relative noise level such that participants and researchers could interact and speak comfortably with each other. Finally, the location needed to be a place where participants had the time to complete the survey process. An example of an inappropriate survey location is the side of a busy street, because such locations can be loud and unsafe, and they don't allow participants enough time to complete the survey. 


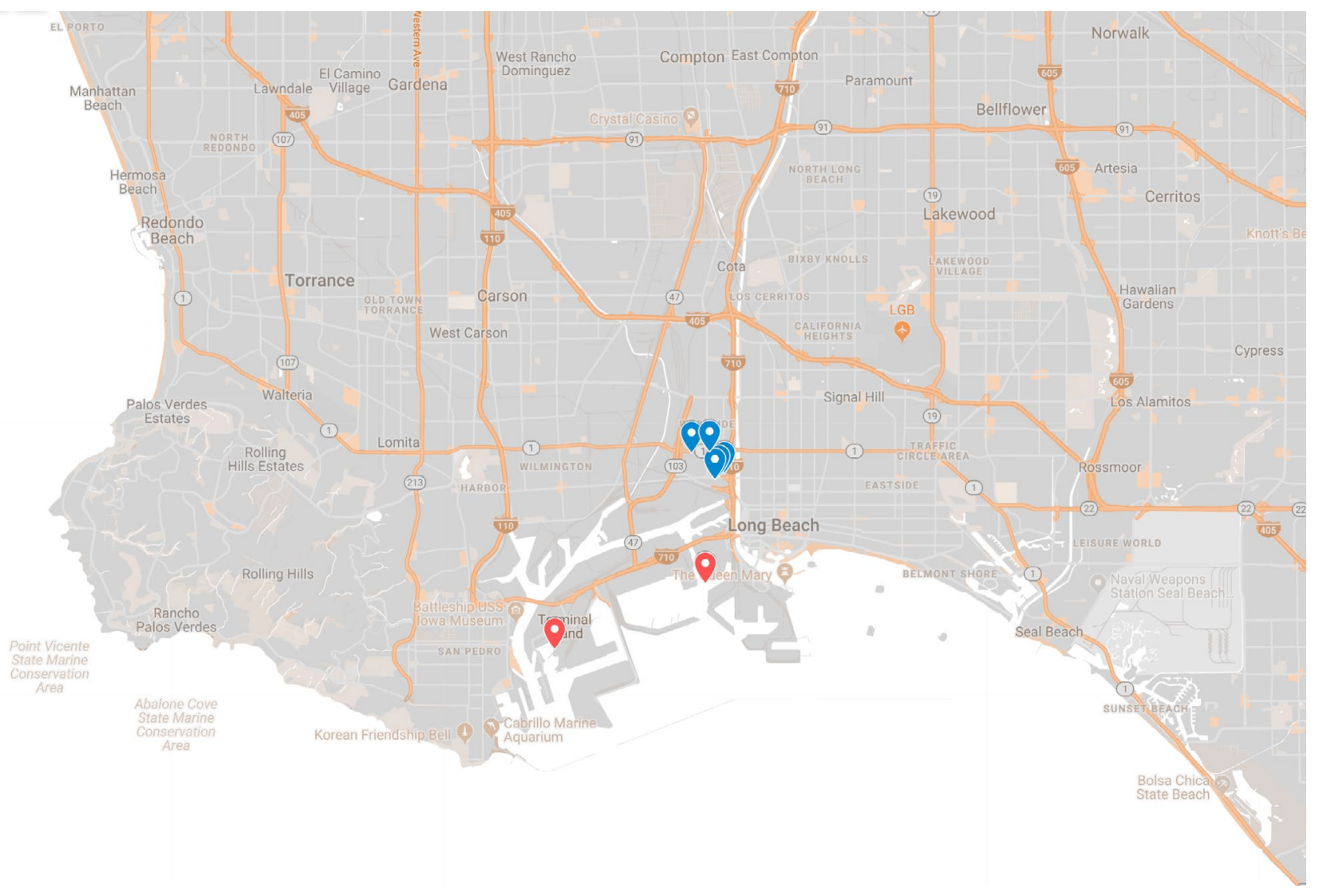

Figure 2. Map of Survey Locations of Interest

In addition to the location selection, the process of finding willing participants, or the "participant requirement," is also a critical stage in the data collection process which is largely dependent on the quality of the survey location selected. Provided that the selected area was suitable, the process of recruiting participants involved approaching drivers, introducing the research team and the purpose of the research, explaining how long the survey would take, and then asking whether drivers owned their truck, and, if so, whether they would be willing to participate in a face-to-face survey. If owner-operator truck drivers agreed to participate in the survey, then the researcher would explain the consent form and remind them that their responses would remain confidential. To assure participants of the confidentiality of the survey, audio was not recorded for the survey. On average, the survey would last more than twenty minutes. Although it is possible for participants to finish the survey in less than ten minutes, it was common for survey respondents to take more time, because many owner-operator truck drivers used the survey as a platform to discuss the economics and lifestyle of being an owner-operator truck driver, as well as the impact of increasing regulations, the current state of the freight industry, and the future of their profession.

\section{DATA COLLECTED}

The writers of this report collected stated-preference survey data by meeting face-to-face with the owner-operator truck drivers. The total number of individuals who attempted the survey was 100 truck drivers. Of those, some truck drivers did not actually participate in 
the survey due to the reasons as follows: (1) they are not an owner-operator truck driver, (2) they are waiting on a client to call them for work, (3) they do not have time to do a survey, (4) they believe that the research advocates for increased tolls, and (5) they also believe that their voice will not be heard or that research will have no impact. Also, some drivers began but did not complete the survey due to one or more of the aforementioned reasons. These incomplete survey data were eliminated from the data analysis. Of those whom the facilitators met, 31 owner-operator truck drivers completed the survey and their responses were used for the data analysis. Respondents used for data analysis possess an average experience of 12.48 years with a median of 10 years. 


\section{RESULTS}

The stated preference survey data obtained from the owner-operator truck drivers are presented after undergoing statistical analysis. First, the willingness of owner-operator truck drivers is examined whether to take truck-only toll lanes under scenarios having different route choice characteristics such as trip origin, trip destination, highway of choice, toll charges, travel time, average speed, reliability, and safety. Also, the tolerated toll fees that owneroperator truck drivers are willing to pay when taking a truck-only toll lane are compared by scenario. Second, the overall preferences of truck-only toll lanes for scenarios having the same origin and destination are compared from the perspectives of owner-operator truck drivers when considering route choices. Third, the comparisons of VOT, VOR, and safety measures are made in terms of the tolerated toll fee amounts in $\$ /$ hour and $\$ /$ mile metrics among the groups of scenarios that have these measures.

Figure 3 shows the percentages of preferences for truck-only toll lanes from 31 respondents by scenario. The percentages of preferences are $67.74 \%, 74.19 \%, 64.52 \%, 74.19 \%$, $74.19 \%, 80.65 \%, 83.87 \%, 74.19 \%$, and $83.87 \%$ for scenarios $1,2,3,4,5,6,7,8$, and 9 , respectively. Owner-operator truck drivers expressed that they prefer to take truck-only toll lanes under each scenario having different route choice characteristics. The responses showed that owner-operator truck drivers prefer to take truck-only toll lanes $75.27 \%$ of the time, on average.

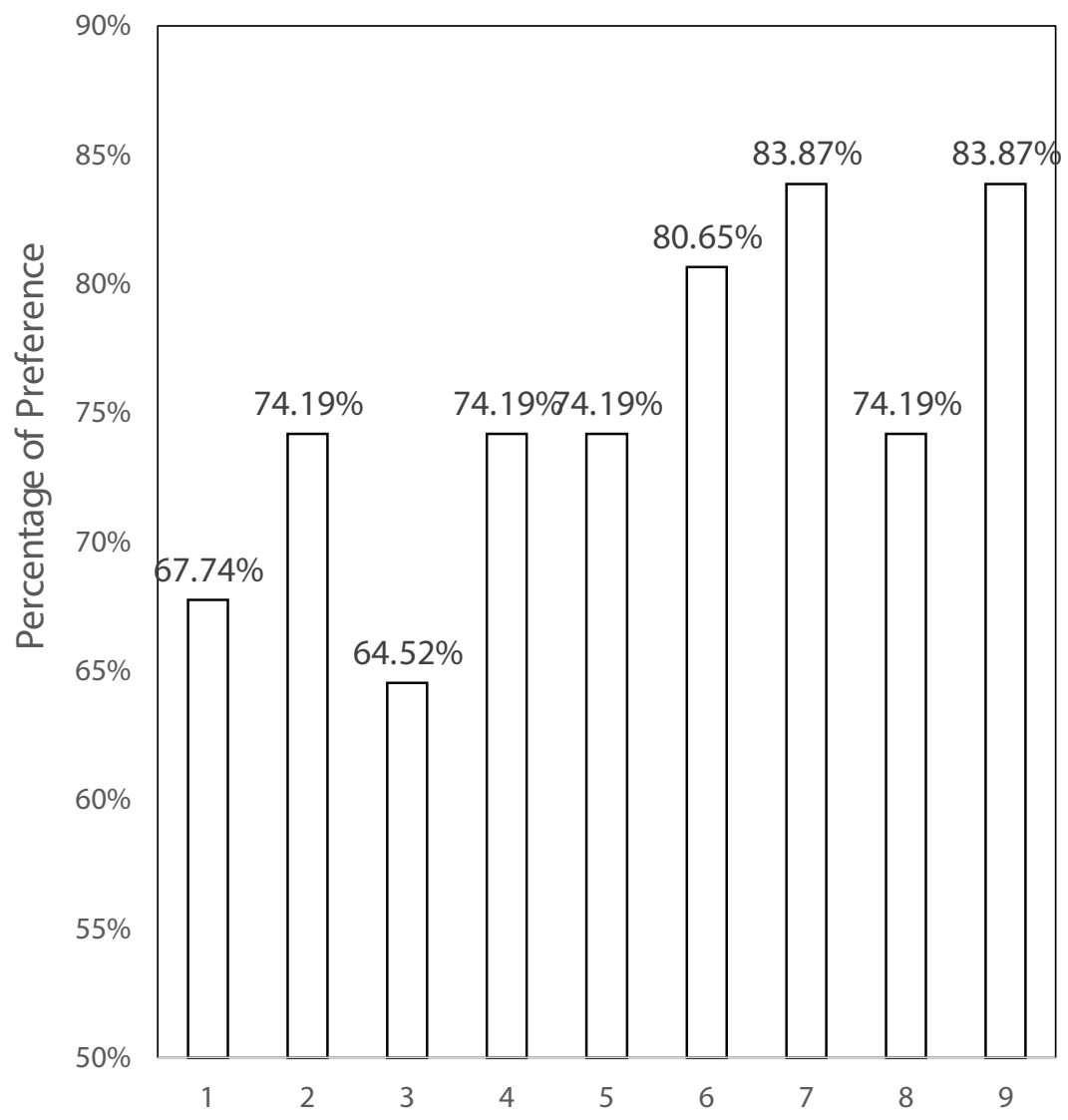

Scenario

Figure 3. Comparison of Respondents' Preference by Scenario 
Table 5 shows the descriptive statistics for the tolerated toll fees by scenario. The tolerated toll fees range from $\$ 4.40 / \mathrm{hr}$ to $\$ 30.97 / \mathrm{hr}$ during weekdays, while those fees range from $\$ 4.40 / \mathrm{hr}$ to $\$ 30.48 / \mathrm{hr}$ during weekends. The tolerated average toll fees are $\$ 13.77 / \mathrm{hr}$ and $\$ 12.82 / \mathrm{hr}$ for weekdays and weekends, respectively. Figure 4 shows the comparison of tolerated toll fees by scenario in $\$$ /hour and $\$$ /mile metrics.

A one-way analysis of variance (ANOVA) is further conducted to compare the mean tolerated toll fees of nine different scenarios. The purpose of the one-way ANOVA is to compare the mean tolerated toll fees among nine scenarios to determine the difference in the extent to which owner-operator truck drivers are willing to pay for truck-only toll lanes when choosing their routes.

Table 5. Descriptive Statistics for Tolerated Toll Fees by Scenario

\begin{tabular}{|c|c|c|c|c|c|c|c|c|}
\hline \multicolumn{2}{|c|}{ Scenario } & \multirow{2}{*}{\begin{tabular}{|l}
$\mathbf{N}$ \\
31
\end{tabular}} & \multirow{2}{*}{$\begin{array}{c}\text { Mean (\$/hour) } \\
10.00\end{array}$} & \multirow{2}{*}{$\begin{array}{c}\text { SE Mean } \\
1.41\end{array}$} & \multirow{2}{*}{$\begin{array}{c}\text { Std. Dev. } \\
7.85\end{array}$} & \multirow{2}{*}{$\begin{array}{r}\text { Median } \\
10.00\end{array}$} & \multirow{2}{*}{$\begin{array}{c}\text { Minimum } \\
0.00\end{array}$} & \multirow{2}{*}{$\begin{array}{c}\text { Maximum } \\
30.00\end{array}$} \\
\hline 1 & Weekdays & & & & & & & \\
\hline & Weekend & 31 & 9.68 & 1.45 & 8.06 & 5.00 & 0.00 & 30.00 \\
\hline \multirow[t]{2}{*}{2} & Weekdays & 31 & 6.52 & 0.981 & 5.46 & 5.000 & 0.000 & 20.00 \\
\hline & Weekend & 31 & 6.10 & 1.00 & 5.59 & 2.00 & 0.00 & 20.00 \\
\hline \multirow[t]{2}{*}{3} & Weekdays & 31 & 15.08 & 2.02 & 11.23 & 10.00 & 0.00 & 40.00 \\
\hline & Weekend & 31 & 14.92 & 2.05 & 11.41 & 10.00 & 0.00 & 40.00 \\
\hline \multirow[t]{2}{*}{4} & Weekdays & 31 & 12.18 & 1.79 & 9.97 & 10.00 & 0.00 & 40.00 \\
\hline & Weekend & 31 & 12.02 & 1.82 & 10.13 & 10.00 & 0.00 & 40.00 \\
\hline \multirow[t]{2}{*}{5} & Weekdays & 31 & 30.97 & 4.40 & 24.51 & 20.00 & 0.00 & 90.00 \\
\hline & Weekend & 31 & 30.48 & 4.32 & 24.06 & 20.00 & 0.00 & 90.00 \\
\hline \multirow[t]{2}{*}{6} & Weekdays & 31 & 24.84 & 2.94 & 16.35 & 20.00 & 10.00 & 60.00 \\
\hline & Weekend & 31 & 24.19 & 3.04 & 16.94 & 15.00 & 0.00 & 60.00 \\
\hline \multirow[t]{2}{*}{7} & Weekdays & 31 & 6.18 & 1.14 & 6.35 & 4.00 & 0.00 & 30.00 \\
\hline & Weekend & 31 & 6.11 & 1.15 & 6.38 & 4.00 & 0.00 & 30.00 \\
\hline \multirow[t]{2}{*}{8} & Weekdays & 31 & 4.40 & 0.84 & 4.66 & 4.000 & 0.000 & 20.00 \\
\hline & Weekend & 31 & 4.40 & 0.84 & 4.66 & 4.000 & 0.000 & 20.00 \\
\hline \multirow[t]{2}{*}{9} & Weekdays & 31 & 7.56 & 1.59 & 8.84 & 5.00 & 0.00 & 40.00 \\
\hline & Weekend & 31 & 7.50 & 1.60 & 8.89 & 5.00 & 0.00 & 40.00 \\
\hline
\end{tabular}




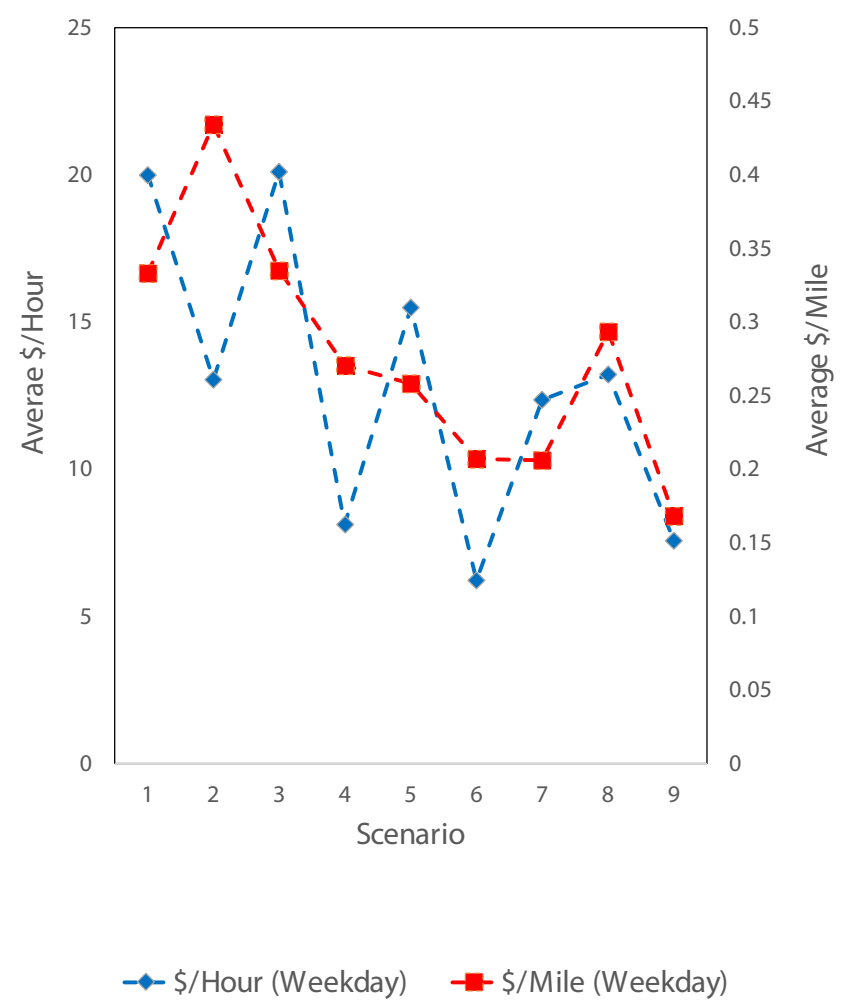

Figure 4. Comparison of Tolerated Toll Fees by Scenario

The ANOVA tests the null hypothesis that nine scenarios are drawn from populations with the same mean values. The authors assumed that owner-operator truck drivers' response variable residuals are normally distributed or approximately normally distributed, the responses are independent, variances of populations are equal, and responses for the scenarios are independent and identically distributed normal random variables. Minitab 19, which is the latest version of one of the software packages, is used for statistical analysis. The one-way ANOVA is used to test whether there is variation in preferences for mean tolerated toll fees across the route choices presented in the various scenarios. The null and alternative hypotheses are $H_{0}: \mu_{s i}=0$ for all $i$, where $i$ is scenario, and $H_{a}$ : at least two mean toll fees among nine scenarios differ. At a 0.05 level of significance, the null hypotheses are rejected because the $p$-value is smaller than 0.05 . The authors have obtained sufficient evidence to show that the null hypothesis is not true.

Table 6 tabulates one-way ANOVA results for the tolerated toll fees that owner-operator truck drivers are willing to pay when they choose routes given the different trip origin, trip destination, highway of choice, toll charges, travel time, average speed, reliability, and safety. Based on the survey data, the test statistic, $F=17.60$, having a $p$-value of 0.000 . $F$-value is a test statistic obtained from data and it is used to compare against the critical $F$-value from the $F$ table. The $p$-value is the probability of obtaining a test statistic as large as the $F$ value, assuming $H_{o}$ is true. Since the $p$-value is less than $\alpha=0.05$, the null hypothesis can be rejected. Therefore, it can be concluded that there is a statistically significant difference among nine groups. Tukey's confidence intervals were created for all pairwise differences to compare the tolerated mean toll fees while controlling the family error rate at a $95 \%$ level. The Tukey $95 \%$ simultaneous confidence intervals for all pairwise comparisons among nine 
scenarios show that half of the pairwise comparisons for the null hypothesis is rejected while the rest of them is not rejected. The results suggest that further analysis is needed to examine to what degree route choice measures such as VOT, VOR, and safety affect the willingness of owner-operator truck drivers to pay the tolerated toll fees.

Table 6. ANOVA Results on Tolerated Toll Fees for All Nine Scenarios

\begin{tabular}{lrcccc}
\hline \multicolumn{1}{c}{ Source } & DF & Adj. SS & Adj. MS & F-Value & P-Value \\
\hline Factor & 8 & 20738 & 2592.3 & 17.60 & 0.000 \\
Error & 270 & 39763 & 147.3 & & \\
Total & 278 & 60501 & & & \\
\hline
\end{tabular}

\section{COMPARISON OF SCENARIOS WITH SAME ORIGIN AND DESTINATION}

This experiment aims to compare the overall preference of truck-only toll lanes for owneroperator truck drivers to choose route choices for the same origin and destination scenarios. The research hypothesis is to examine whether there is a significant difference in their preferences between two scenarios. The difference is a metric to show whether owneroperator truck drivers prefer truck-only toll lanes. In most cases, the actual variance or standard deviation of either of the two population groups is not known. It is assumed that route choice preference samples are randomly and independently drawn from respective owner-operator truck drivers that are normally distributed and that the population variances are equal. Thus, the experiment method using two sample $t$-tests assuming equal variance is appropriate because it determines whether a significant difference exists between the means of the two populations. The authors conducted two-sample $t$-tests for the hypothesis testing using Minitab 19. The hypothesis to test is to examine whether the overall preferences indicate a willingness to pay toll fees on truck-only toll lanes $\left(\mu_{1}\right)$ exceeding those not willing to pay toll fees $\left(\mu_{2}\right)$. The mathematical form of the hypothesis is that $H_{0}: \mu_{1}-\mu_{2}=0$ and $H_{a}$ : $\mu_{1}-\mu_{2}>0$. Table 7 shows the statistical results for the scenarios that have the same origins and destinations.

Table 7. Statistical Results for Same Origin and Destination

\begin{tabular}{cccccc}
\hline Comparison & Difference & Pooled Std. Dev. & 95\% CI for Difference & T-value & $P$-value \\
\hline 1 vs. 7 & 3.82 & 7.14 & $(0.20,7.45)$ & 2.11 & 0.039 \\
2 vs. 8 & 2.11 & 5.08 & $(-0.47,4.69)$ & 1.64 & 0.107 \\
3 vs. 4 & -2.90 & 10.062 & $(-8.99,3.19)$ & -1.14 & 0.495 \\
3 vs. 9 & -7.52 & 10.062 & $(-13.61,-1.43)$ & -2.94 & 0.011 \\
4 vs. 9 & -4.61 & 10.062 & $(-10.70,1.48)$ & -1.80 & 0.174 \\
5 vs. 6 & 6.13 & 20.83 & $(-4.46,16.71)$ & 1.16 & 0.251 \\
\hline
\end{tabular}

Six comparisons are made between two scenarios having the same origin and destination but different route choice characteristics. At a 0.05 level of significance, the null hypotheses are rejected for the comparisons of scenarios $1 \& 7$ and $3 \& 9$, respectively, because the $\mathrm{p}$-value is smaller than 0.05 . There is sufficient evidence to show that the null hypothesis is not true. Scenarios $1 \& 7$ have the same route from Port of Los Angeles on I-110 to 
Pasadena, but their characteristics are different in that scenario 1 focuses on the VOT measure while scenario 7 is based on the safety measure. This finding is similar for scenarios $3 \& 9$ having the same route from Port of Long Beach on I-405 to Van Nuys. Their characteristics are also different in that scenario 3 focuses on the VOT measure while scenario 9 is based on the safety measure. This means that owner-operator truck drivers showed a different preference to take truck-only toll lanes when choosing between two routes. From this result, it is not conclusive that owner-operator truck drivers will take truck-only toll lanes, because they consider the tradeoff between VOT and safety measures to be salient.

On the other hand, the null hypotheses are not rejected for four comparisons out of six comparisons having same origins and destinations, but different route choice characteristics. These four comparisons include scenarios $2 \& 8,3 \& 4,4 \& 9$, and $5 \& 6$, respectively. The p-values in the comparisons are larger than 0.05 , which means that owner-operator truck drivers showed their impartial preference to take truck-only toll lanes when they choose the routes from Port of Long Beach on I-710 to Campton, Port of Long Beach on I-405 to Van Nuys, and Port of Los Angeles on I-5 to San Diego.

Scenarios 2 \& 8 have the same route from Port of Long Beach on I-710 to Compton) but their characteristics are different in that scenario 2 focuses on the VOR measure while scenario 8 is based on the safety measure. Scenarios $3 \& 4$ also have the same route from Port of Long Beach on I-405 to Van Nuys, but their characteristics are different in that scenario 3 focuses on the VOT measure while scenario 4 is based on the VOR measure. Scenarios 4 \& 9 have the same route from Port of Long Beach on I-405 to Van Nuys, but their characteristics are different in that scenario 4 focuses on the VOR measure while scenario 9 is based on the safety measure. Scenarios $5 \& 6$ have the same route from Port of Los Angeles on I-5 to San Diego, but their characteristics are different in that scenario 5 focuses on the VOT measure while scenario 6 is based on the VOR measure. From this result, it is conclusive that owner-operator truck drivers will take truck-only toll lanes when they take these routes, even though different measures are considered when making decisions about route choices.

\section{RESULTS: VALUE OF TIME SCENARIOS}

Scenarios 1,3 , and 5 vary in route factors such as the trip origin, trip destination, highway of choice, toll charges, travel time, average speed, reliability, and safety. However, the key factor to be considered is value of time. For each given scenario, owner-operator truck drivers are to state whether they prefer to take truck-only toll lanes and record the most amount of money they are willing to pay. Table 8 shows the grouping of three scenarios to demonstrate the variance in the VOT measure. 
Table 8. Stated Preference Scenarios for VOT

\begin{tabular}{llll}
\hline Scenario No. (Route key factor) & \multicolumn{1}{c}{ Scenario 1 (VOT) } & \multicolumn{1}{c}{ Scenario 3 (VOT) } & \multicolumn{1}{c}{ Scenario 5 (VOT) } \\
\hline Origin & Port of LA on I 110 & Long Beach on 1405 & Los Angeles on I 5 \\
Destination & Pasadena & Van Nuys & San Diego \\
Distance (miles) & 30 & 45 & 120 \\
Toll Charges (USD) & 15 & 30 & 60 \\
Travel Time (minutes) & 30 & 45 & 120 \\
Average Speed (mph) & 60 & 60 & 60 \\
\hline
\end{tabular}

Table 9 tabulates the tolerated toll fee results for the VOT measure in terms of $\$ /$ mile and $\$$ / hour metrics. It is found that the difference between weekday and weekend values for the highest toll fee per mile and highest toll fee per hour is negligible, with the overall percent difference between weekday and weekend values being $2 \%$ for both $\$ /$ mile and $\$ /$ hour. Additionally, the highest toll fee per mile on any day that drivers are willing to pay when the main factor being compared is the VOT measure is $\$ 0.31$ per mile. In other words, the highest toll fee per hour on any day that drivers are willing to pay when the main factor being compared is the VOT measure is $\$ 18.35$ per hour.

Table 9. Results on Estimation for VOT Measures

\begin{tabular}{lcccc}
\hline \multicolumn{1}{c}{ Scenario No. } & \$/Mile (Weekday) & \$/Mile (Weekend) & \$/Hour (Weekday) & \$/Hour (Weekend) \\
\hline 1 & 0.33 & 0.32 & 20.00 & 19.35 \\
3 & 0.34 & 0.33 & 20.11 & 19.89 \\
5 & 0.26 & 0.25 & 15.48 & 15.24 \\
Column Average & 0.31 & 0.30 & 18.53 & 18.16 \\
Weekday/Weekend Average & 0.31 & & 18.35 & \\
\hline
\end{tabular}

\section{RESULTS: VALUE OF RELIABILITY SCENARIOS}

The key factor to be considered for scenarios 2,4 , and 6 is the value of reliability. The survey describes reliability as a key factor with scenarios 2,4 , and 6 by comparing the likelihood of short and long travel times. For instance, scenario 2 describes a 15 mile trip from the Port of Long Beach to Compton using I-710, where the lack of a toll lane ensures a $50 \%$ chance of a 15-minute total travel time and a $50 \%$ chance of a 60 -minute total travel. However, the use of a toll lane ensures a $100 \%$ chance of a 30 -minute total travel time. Scenarios 4 and 6 follow a similar pattern as scenario 2 . These scenarios have been grouped below to show the average highest toll fee per mile and average highest toll fee per hour that drivers are willing to pay for increased reliability. Table 10 shows the grouping of three scenarios to demonstrate the variance in the VOR measure. 
Table 10. Stated Preference Scenarios for VOR

\begin{tabular}{llll}
\hline Scenario No. (Route key factor) & \multicolumn{1}{c}{ Scenario 2 (VOR) } & Scenario 4 (VOR) & Scenario 6 (VOR) \\
\hline Origin & Port of Long Beach on I 710 & Long Beach on I 405 & Los Angeles on I 5 \\
Destination & Compton & Van Nuys & San Diego \\
Distance (miles) & 15 & 45 & 120 \\
Toll Charges (USD) & 10 & 15 & 30 \\
Travel Time (minutes) & 30 & 90 & 240 \\
Average Speed (mph) & 30 & 30 & 30 \\
\hline
\end{tabular}

Table 11 tabulates the tolerated toll fee results on the VOR measure in terms of $\$ /$ mile and $\$$ / hour. It is found that the difference between weekday and weekend values for the highest toll fee per mile and highest toll fee per hour is negligible, with the percent difference between weekday and weekend values being less than $\mathbf{5 \%}$ for both $\$ /$ mile and $\$ /$ hour. Additionally, the highest toll fee per mile on any day that drivers are willing to pay when the main factor being compared is the VOR measure is $\$ 0.30$ per mile. In other words, the highest toll fee per hour on any day that drivers are willing to pay when the main factor being compared is the VOR measure is $\$ 8.94$ per hour.

Table 11. Results on Estimation for VOR Measures

\begin{tabular}{lcccc}
\hline \multicolumn{1}{c}{ Scenario No. } & \$/Mile (Weekday) & \$/Mile (Weekend) & \$/Hour (Weekday) & \$/Hour (Weekend) \\
\hline 2 & 0.21 & 0.20 & 12.35 & 12.23 \\
4 & 0.29 & 0.29 & 13.21 & 13.21 \\
6 & 0.17 & 0.17 & 7.56 & 7.50 \\
\hline Column Average & 0.30 & 0.29 & 9.12 & 8.75 \\
Weekday/Weekend Average & 0.30 & & 8.94 & \\
\hline
\end{tabular}

\section{RESULTS: SAFETY SCENARIOS}

Scenarios 7,8 , and 9 vary in the aforementioned route factors and compare the safety measure as a key factor. The survey describes safety as a key factor in terms of the time of day of the trip, the presence or absence of passenger cars , and weather conditions such as heavy rain or no rain. Consequently, scenarios 7,8 , and 9 have been grouped below to show the differences in route factors. Table 12 shows the grouping of three scenarios to demonstrate the variance in the safety measure.

Table 13 shows the tolerated toll fee results for safety measures in terms of $\$ /$ mile and $\$ /$ hour. It is found that the difference between weekday and weekend values for the highest toll fee per mile and highest toll fee per hour is negligible, with the percent difference between weekday and weekend values being $1 \%$ for both $\$ /$ mile and $\$ /$ hour. Additionally, the highest toll fee per mile on any day that drivers are willing to pay when the main factor being compared is the safety measure is $\$ 0.22$ per mile. In other words, the highest toll fee per hour on any day that drivers are willing to pay when the main factor being compared is the safety measure is $\$ 11.01$ per hour. 
Table 12. Stated Preference Scenarios for Safety Measures

\begin{tabular}{llll}
\hline Scenario No. (Route key factor) & Scenario 7 (Safety) & Scenario 8 (Safety) & Scenario 9 (Safety) \\
\hline Origin & Port of LA on I 110 & Port of Long Beach on I 710 & Long Beach on I 405 \\
Destination & Pasadena & Compton & Van Nuys \\
Distance (miles) & 30 & 15 & 45 \\
Toll Charges (USD) & 5 & 5 & 5 \\
Travel Time (minutes) & 30 & 20 & 60 \\
Average Speed (mph) & 60 & 45 & 45 \\
\hline
\end{tabular}

Table 13. Results on Estimation for Safety Measures

\begin{tabular}{lcccc}
\hline \multicolumn{1}{c}{ Scenario No. } & \$/Mile (Weekday) & \$/Mile (Weekend) & \$/Hour (Weekday) & \$/Hour (Weekend) \\
\hline 7 & 0.21 & 0.20 & 12.35 & 12.23 \\
8 & 0.29 & 0.29 & 13.21 & 13.21 \\
9 & 0.17 & 0.17 & 7.56 & 7.50 \\
\hline Column Average & 0.22 & 0.22 & 11.04 & 10.98 \\
Weekday/Weekend Average & 0.22 & & 11.01 & \\
\hline
\end{tabular}

Table 14 summarizes the comparison results of values for tolerated toll fee per mile and toll fee per hour metrics as they relate to VOT, VOR, and safety measures. For all values, a negligible difference was found in drivers' willingness to pay for tolls when comparing weekday and weekend usage. When using VOR as a key comparison factor, the results indicate that drivers value reliability similarly to the way they value safety when measured in toll fee per mile. However, when measuring in toll fee per hour, drivers' value for safety is more than twice as great compared to their value for reliability. Of the three key comparison factors, in terms of toll fee per mile, drivers are least willing to pay for tolls when using VOT as a key comparison factor and most willing when considering the safety measure to be the key comparison factor. In all cases, drivers' valuation of the safety measure outweighs their valuation of reliability and time.

Table 14. Summary of Results on Key Measures

\begin{tabular}{lrccc}
\hline Route Key Measure (Scenarios) & \$/Mile & \$/Hour & \% Difference (Weekday) & \% Difference (Weekend) \\
\hline VOT $(1,3,5)$ & 0.22 & 11.01 & $2 \%$ & $2 \%$ \\
VOR $(2,4,6)$ & 0.30 & 8.94 & $4 \%$ & $4 \%$ \\
Safety $(7,8,9)$ & 0.31 & 18.35 & $1 \%$ & $1 \%$ \\
\hline
\end{tabular}




\section{CONCLUSIONS}

This research implemented the stated preference survey method in the field to estimate the value placed on time, reliability, and safety by owner-operator truck drivers when choosing among travel routes. The statistical analysis used a complete set of 31 stated preference survey responses obtained from owner-operator truck drivers and yielded the following findings.

1. The response showed that $75.27 \%$ of owner-operator truck drivers are able to pay toll fees on average for nine scenarios having different route choice characteristics.

2. The tolerated toll fees drivers were willing to pay ranged from $\$ 4.40 / \mathrm{hr}$ to $\$ 30.97 /$ $\mathrm{hr}$ during weekdays, while those fees ranged from $\$ 4.40 / \mathrm{hr}$ to $\$ 30.48 / \mathrm{hr}$ during weekends. The average toll fees are $\$ 13.77 / \mathrm{hr}$ and $\$ 12.82 / \mathrm{hr}$ for weekdays and weekends, respectively.

3. The data analysis showed that owner-operator truck drivers are not willing to pay toll fees for the routes used in two out of six comparisons despite sharing a common origin and destination. The rational is that they consider the tradeoff between VOT and safety measures. However, it is conclusive that owner-operator truck drivers are willing to pay toll fees for the routes used in four out of six comparisons, despite sharing a common origin and destination. The reason is that the routes considered in the comparisons are more important than measures considered for their route choice decisions.

4. The highest toll fee per mile on any day that drivers are willing to pay when the main factor being compared is VOT is $\$ 0.31 / \mathrm{mile}$ or $\$ 18.35 / \mathrm{hr}$. The figures for the VOR and safety measures are $\$ 0.30 / \mathrm{mile}$ or $\$ 8.94 / \mathrm{hr}$ and $\$ 0.22 / \mathrm{mile}$ or $\$ 11.01 / \mathrm{hr}$, respectively. The difference in values for all three measures is negligible between weekdays and weekends.

When using VOR as a key comparison factor, the results also indicate that drivers value reliability similarly to the way they value safety when measured in toll fee per mile. However, when measuring in toll fee per hour, drivers' value of safety is more than two times greater than their value of reliability. Of the three key comparison factors, in terms of toll fee per mile, drivers are least willing to pay for tolls when using VOT as a key comparison factor and most willing when considering the safety measure to be the key comparison factor. In all cases, drivers' value for the safety measure outweighs their value of reliability and value of time.

While this report has presented transportation agencies with meaningful data on owneroperator truck drivers' behaviors and patterns, several critical limitations remain. Some of the open research areas to address these limitations for the research community include:

- Need to obtain more data. Since the stated preference survey method with owneroperator truck drivers is challenging due to several reasons previously mentioned, a creative and efficient way to identify owner-operator truck drivers is needed. 
- Need to expand this work to encompass both owner-operator truck drivers and company truck drivers. One of the major challenges is that this research does not include truck drivers who work for a company. Thus, a comparative study including these truck drivers will help enhance truck drivers' route choice results to better understand travel patterns. 


\section{APPENDIX A: STATED PREFERENCE SURVEY}

Approved November 27, 2019 by the CSULB IRB

\section{Preliminary Questions}

Yes

No

Do you own and

operate your own

O

O

vehicle?

Do you ever go to

the Port of Long

O

0

Beach?

Do you ever go to

the Port of Los

Angeles?

0

O

23

34

45

7 or

How many axles

does your vehicle

have?

$\bigcirc \quad \bigcirc$

0

0

0

$1-5$

$6-10$

$11-15$

$16-20$

21 or more

How many years

of experience do

you have?

Figure 5. SP Survey Preliminary Questions 


\section{Part II. Value of time and reliability}

\section{Consider the scenario presented below and answer the following} questions.

\begin{tabular}{|c|c|c|}
\hline \multicolumn{2}{|c|}{ Not on toll lanes, heavy traffic } & \multicolumn{2}{|c|}{ On toll lanes, little/no traffic } \\
\hline & & \\
\hline
\end{tabular}

Do you prefer this toll charge?

$\bigcirc$ Yes

No

Amount you would be willing to pay on a...

Weekday (Mon-

Thu)

O

$\bigcirc$

○

O

$\mathrm{O}$

$\bigcirc$

Weekend (FriSun)<smiles>O</smiles><smiles>O</smiles>

O

O

O

$\bigcirc$

Figure 6. SP Survey Questionnaire for Scenario 1 


\section{Consider the scenario presented below and answer the following questions.}

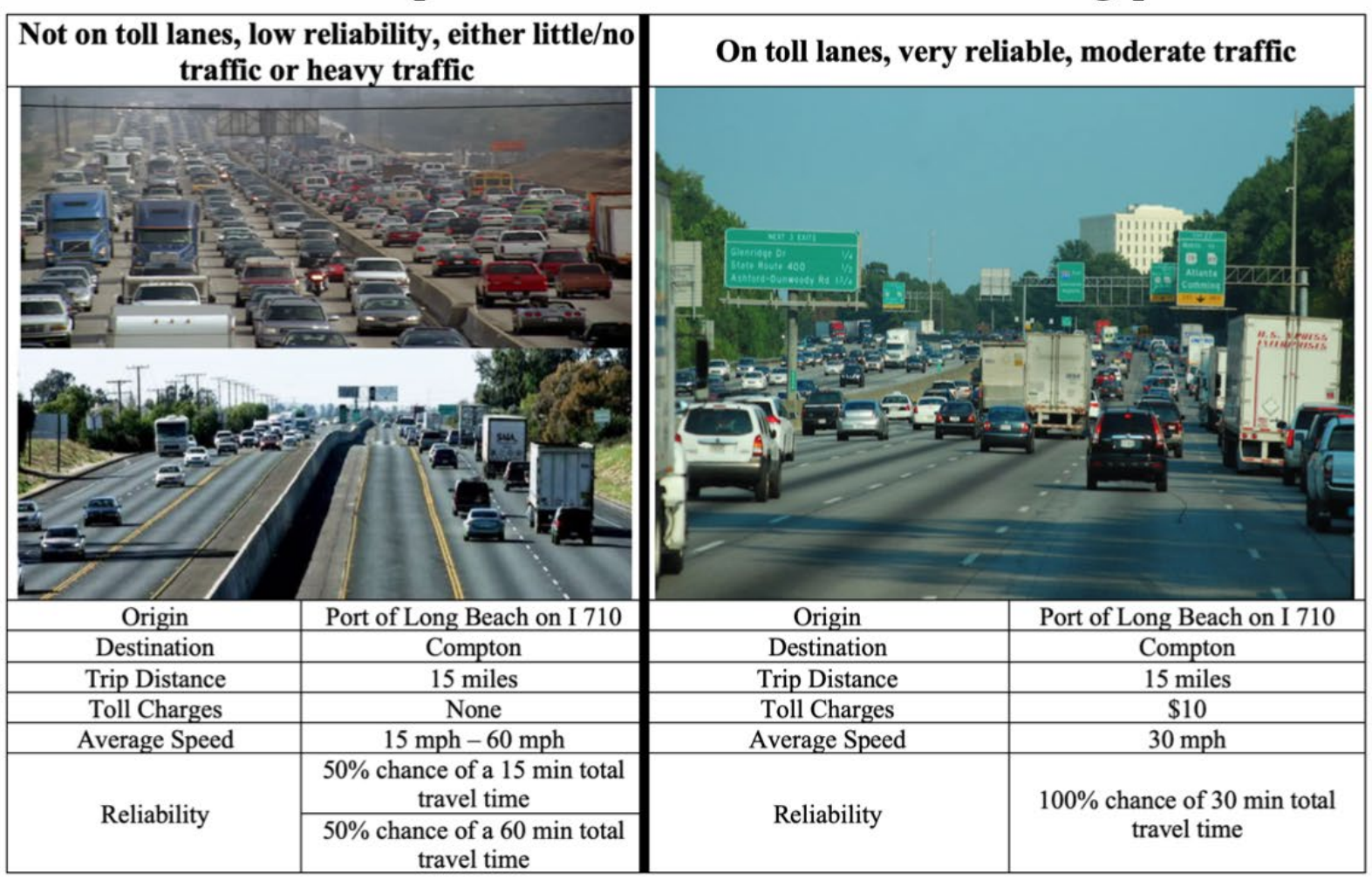

\section{Do you prefer this toll charge?}

Yes

No

\section{Amount you would be willing to pay on a...}

$\begin{array}{lcccccc} & \$ 2 & \$ 5 & \$ 8 & \$ 10 & \$ 15 & \$ 20 \\ \begin{array}{l}\text { Weekday (Mon- } \\ \text { Thu) }\end{array} & \bigcirc & \bigcirc & \bigcirc & \bigcirc & \bigcirc & \bigcirc \\ \begin{array}{l}\text { Weekend (Fri- } \\ \text { Sun) }\end{array} & \bigcirc & \bigcirc & \bigcirc & \bigcirc & \bigcirc & \bigcirc\end{array}$

Figure 7. SP Survey Questionnaire for Scenario 2 
4. Consider the scenario presented below and answer the following questions.

\begin{tabular}{|c|c|c|}
\hline \multicolumn{2}{|c|}{ Not on toll lanes, heavy traffic } & On toll lanes, little/no traffic \\
\hline & & \\
\hline
\end{tabular}

Do you prefer this toll charge?

$\bigcirc$ Yes

No

Amount you would be willing to pay on a...

$\$ 10 \quad \$ 20 \quad \$ 30 \quad \$ 40 \quad \$ 50 \quad \$ 60$

Weekday (Mon-

Thu)

$\bigcirc \quad \bigcirc$

$\bigcirc$

○

$\bigcirc$

O

Weekend (Fri-

Sun)

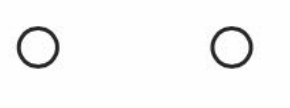

$\bigcirc$

O

O

O

Figure 8. SP Survey Questionnaire for Scenario 3 
5. Consider the scenario presented below and answer the following questions.

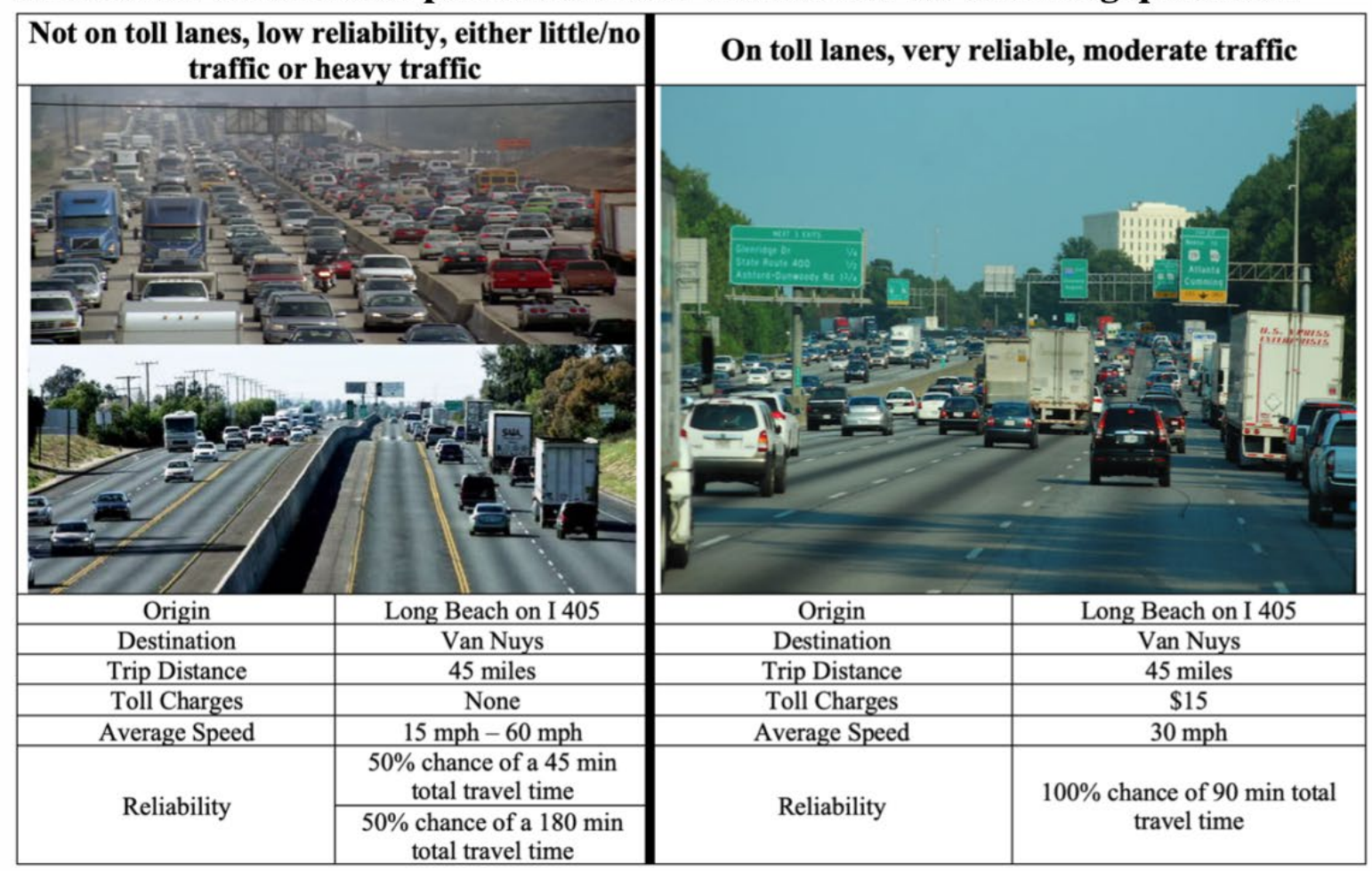

Do you prefer this toll charge?

Yes

No

Amount you would be willing to pay on a...

$\begin{array}{lcccccc} & \$ 5 & \$ 10 & \$ 15 & \$ 20 & \$ 30 & \$ 40 \\ \begin{array}{l}\text { Weekday (Mon- } \\ \text { Thu) }\end{array} & \bigcirc & \bigcirc & \bigcirc & \bigcirc & \bigcirc & \bigcirc \\ \begin{array}{l}\text { Weekend (Fri- } \\ \text { Sun) }\end{array} & \bigcirc & \bigcirc & \bigcirc & \bigcirc & \bigcirc & \bigcirc\end{array}$

Figure 9. SP Survey Questionnaire for Scenario 4 


\section{Consider the scenario presented below and answer the following questions.}

\begin{tabular}{|c|c|c|}
\hline \multicolumn{2}{|c|}{ Not on toll lanes, heavy traffic } & \multicolumn{2}{|c|}{ On toll lanes, little/no traffic } \\
\hline & & \\
\hline
\end{tabular}

\section{Do you prefer this toll charge?}

$\bigcirc$ Yes

No

\section{Amount you would be willing to pay on a...}

\begin{tabular}{|c|c|c|c|c|c|}
\hline & $\$ 15$ & $\$ 30$ & $\$ 45$ & $\$ 60$ & $\$ 90$ \\
\hline $\begin{array}{l}\text { Weekday (Mon- } \\
\text { Thu) }\end{array}$ & $\bigcirc$ & 0 & 0 & 0 & 0 \\
\hline $\begin{array}{l}\text { Weekend (Fri- } \\
\text { Sun) }\end{array}$ & 0 & 0 & 0 & 0 & 0 \\
\hline
\end{tabular}

Figure 10. SP Survey Questionnaire for Scenario 5 
7. Consider the scenario presented below and answer the following questions.

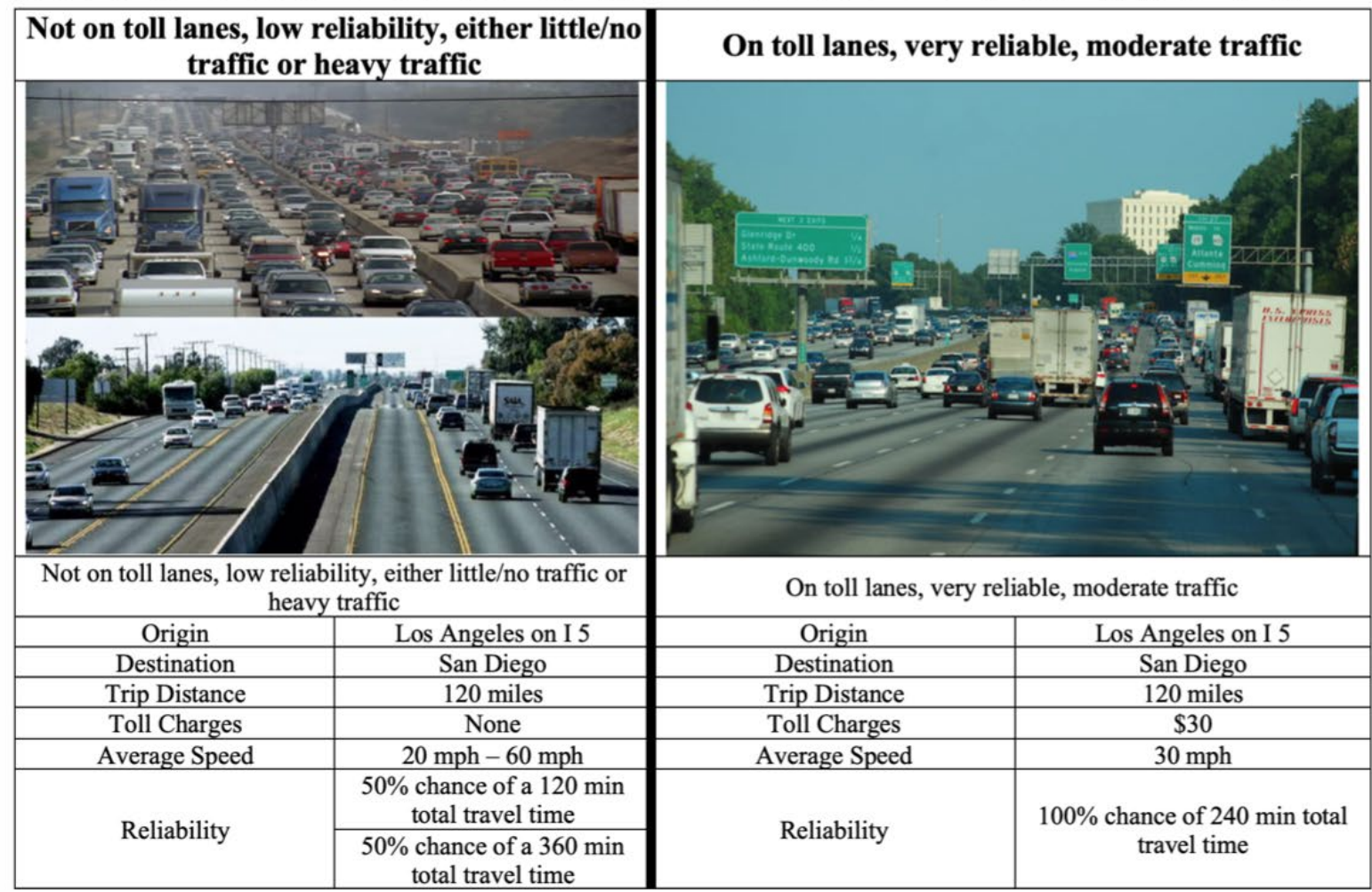

\section{Do you prefer this toll charge?}
$\bigcirc$ Yes
$\bigcirc$ No

\section{Amount you would be willing to pay on a...}

$\begin{array}{lllllll} & \$ 10 & \$ 20 & \$ 30 & \$ 40 & \$ 50 & \$ 60 \\ \begin{array}{l}\text { Weekday (Mon- } \\ \begin{array}{l}\text { Thu) } \\ \text { Weekend (Fri- }\end{array}\end{array} & \bigcirc & \bigcirc & \bigcirc & \bigcirc & \bigcirc & \bigcirc \\ \begin{array}{l}\text { Sun) } \\ \text { W }\end{array} & \bigcirc & \bigcirc & \bigcirc & \bigcirc & \bigcirc & \bigcirc\end{array}$

Figure 11. SP Survey Questionnaire for Scenario 6 


\section{Consider the scenario presented below and answer the following questions.}

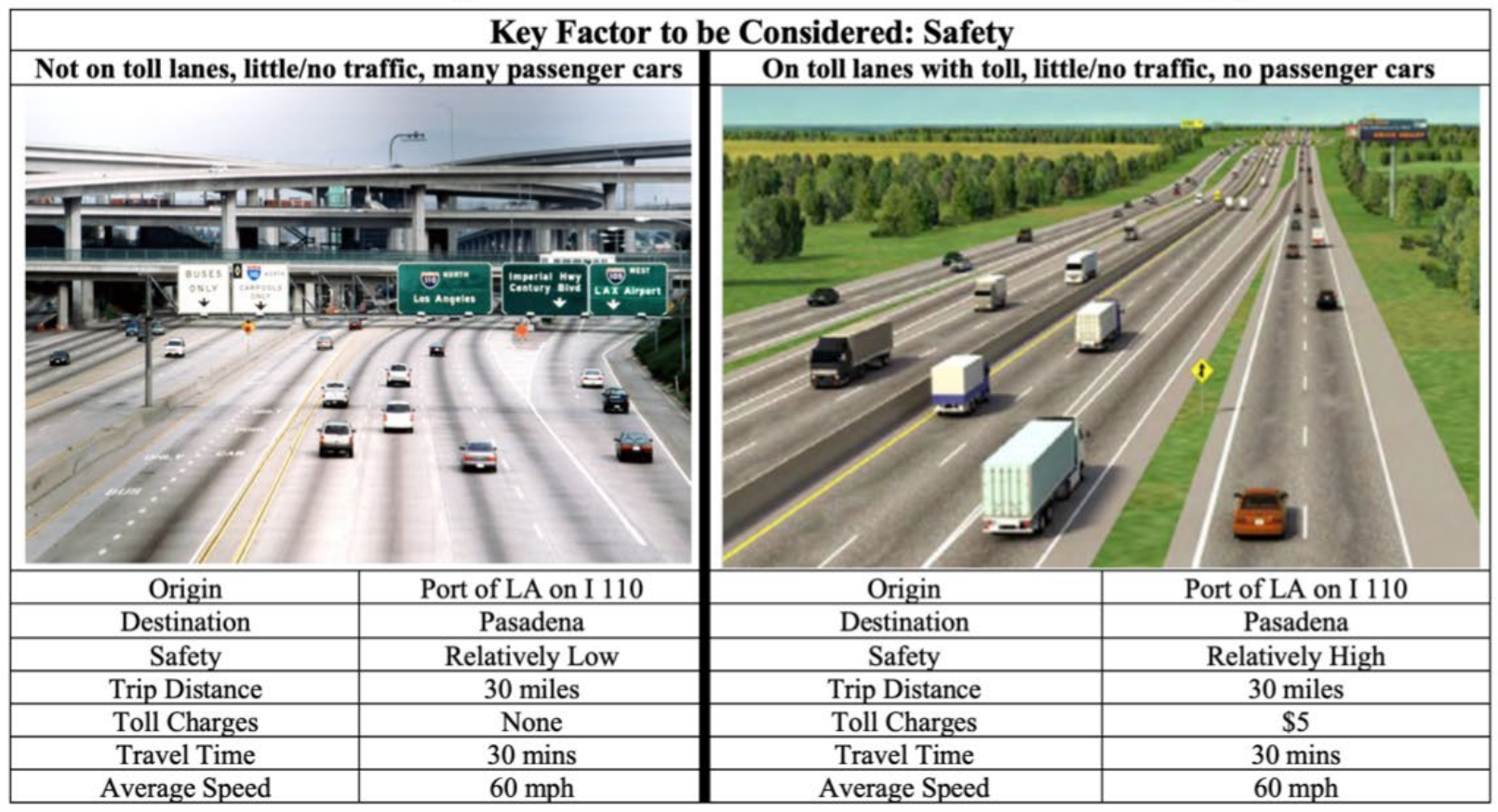

\section{Do you prefer this toll charge?}
$\bigcirc$ Yes
No

Amount you would be willing to pay on a...

Weekday (Mon-

Thu)

Weekend (Fri-

Sun)
0

O

O
O

O

O
$O$
O

O

O

O

O

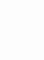




\section{Consider the scenario presented below and answer the following questions.}

\begin{tabular}{|c|c|c|}
\hline \multicolumn{2}{|c|}{ Key Factors to be Considered: Safety and Weather } \\
\hline Not on toll lanes, little/no traffic, raining heavily \\
\hline MAERSK
\end{tabular}

\section{Do you prefer this toll charge?}
Yes
No

\section{Amount you would be willing to pay on a...}

$\begin{array}{lllllll} & \$ 0 & \$ 2 & \$ 4 & \$ 6 & \$ 8 & \$ 30 \\ \begin{array}{l}\text { Weekday (Mon- } \\ \text { Thu) }\end{array} & \bigcirc & \bigcirc & \bigcirc & \bigcirc & \bigcirc & \bigcirc \\ \begin{array}{l}\text { Weekend (Fri- } \\ \text { Sun) }\end{array} & \bigcirc & \bigcirc & \bigcirc & \bigcirc & \bigcirc & \bigcirc\end{array}$

Figure 13. SP Survey Questionnaire for Scenario 8 


\section{Consider the scenario presented below and answer the following questions.}

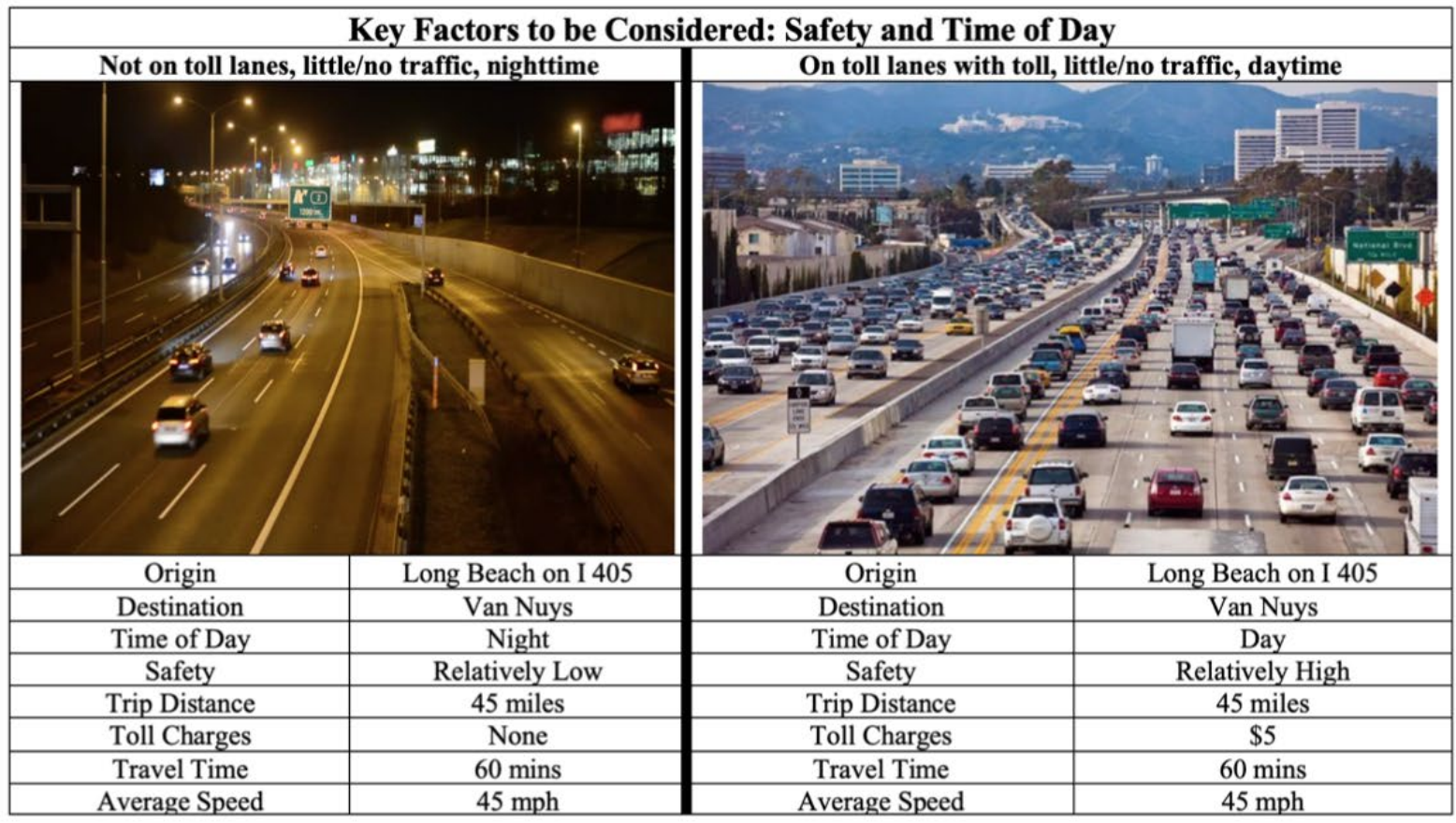

\section{Do you prefer this toll charge?}

Yes

No

\section{Amount you would be willing to pay on a...}

$\begin{array}{llllll}\$ 0 & \$ 2 & \$ 4 & \$ 6 & \$ 8 & \$ 10\end{array}$

Weekday (MonThu)

O

O

O

Weekend (FriSun)

0

0

$O$

\section{O \\ O}

$O$

$O$ 


\section{ABBREVIATIONS AND ACRONYMS}

\begin{tabular}{ll}
\hline ANOVA & Analysis of Variance \\
IRB & Insitutional Research Board \\
LM & Logit Model \\
MRS & Marginal Rate of Substitution \\
RP & Revealed Preference \\
SCAG & Southern California Association of Governments \\
SP & Stated Preference \\
VOR & Value of Travel Reliability \\
VOT & Valuation of Time \\
WR & Wage Rate \\
\hline
\end{tabular}




\section{BIBLIOGRAPHY}

Álvarez, Óscar, Pedro Cantos, and Leandro García. "The Value of Time and Transport Policies in a Parallel Road Network." Transport Policy 14, no. 5 (2007): 366-76. https://doi.org/10.1016/j.tranpol.2007.04.012

Asensio, Javier, and Anna Matas. "Commuters' Valuation of Travel Time Variability." Transportation Research Part E: Logistics and Transportation Review 44, no. 6 (2008): 1074-85. https://doi.org/10.1016/j.tre.2007.12.002

Brownstone, David, and Kenneth A. Small. "Valuing Time and Reliability: Assessing the Evidence from Road Pricing Demonstrations." Transportation Research Part A: Policy and Practice 39, no. 4 (2005): 279-93. https://doi.org/10.1016/j. tra.2004.11.001

Calfee, John, and Clifford Winston. "The Value of Automobile Travel Time: Implications for Congestion Policy." Journal of Public Economics 69, no. 1 (1998): 83-102. https://doi.org/https://doi.org/10.1016/S0047-2727(97)00095-9

Carrion, Carlos, and David Levinson. "Valuation of Travel Time Reliability from a GPS-Based Experimental Design." Transportation Research Part C: Emerging Technologies 35 (2013): 305-23. https://doi.org/https://doi.org/10.1016/j. trc.2012.10.010.

Choi, Chang-Ho. "Value of Freight Travel-Time Savings for Road Investment Evaluation." Journal of Korean Society of Transportation 20, no. 3 (2002): 41-52.

Choi, Chang-Ho. "A Study on Estimating the Value of Travel Time of Freight Transportation for Toll Roads Investment Evaluation." Journal of the Korea Land Studies 43 (2004): 3-15.

Cirillo, C., and K. W. Axhausen. "Evidence on the Distribution of Values of Travel Time Savings from a Six-Week Diary." Transportation Research Part A: Policy and Practice 40, no. 5 (2006): 444-57. https://doi.org/10.1016/j.tra.2005.06.007

de Jong, Gerard. "Value of Freight Travel-Time Savings." In Handbook of Transport Modelling, edited by A. Hensher David and J. Button Kenneth, 649-63: Emerald Group Publishing Limited, 2007.

de Jong, Gerard, Carine Vellay, and Michel Houée. "A Joint SP/RP Model of Freight Shipment from the Region Nord-Pas De Calais." Proceedings of the AET European Transport Conference, September 10-12, 2001, Homerton College, Cambridge, UK.

Ehreke, Ilka, Stephane Hess, Claude Weis, and Kay W. Axhausen. "Reliability in the German Value of Time Study." Transportation Research Record 2495, no. 1 (2015): 14-22. https://doi.org/10.3141/2495-02. 
Fehmarn Belt Traffic Consortium. Fehmarn Belt Traffic Demand Study. Danish and German Ministries of Transport, FTC, Copenhagen, Final report, 1999.

FHWA. Hers-St V2.0 Highway Economic Requirements System-State Version: Technical Report. U.S. Dept. of Transportation, Federal Highway Administration (Washington, D.C.: 2002). Accessed May 1, 2020. https://permanent.access.gpo. gov/lps57467//ps57467/isddc.dot.gov/OLPFiles/FHWA/010945.pdf.

Georgia State Road and Tollway Authority (2006). "Value Pricing on the I-75 HOV/BRT Project." Accessed October 15, 2019. http://www.georgiatolls.com/SRTAExternal/ pdf/i-75hov-brt-project.pdf.

Ghosh, Arindam. "Valuing Time and Reliability: Commuters' Mode Choice from a Real Time Congestion Pricing Experiment." PhD diss., University of California Irvine, 2001.

Hayashi, Yoshihiko, and Hisayoshi Morisugi. "International Comparisons of Background Concept and Methodology of Transportation Project Appraisal." Transport Policy 7, no. 1 (2000): 73-88. https://doi.org/https://doi.org/10.1016/S0967070X(00)00015-9

Hossan, Md Sakoat. "Impacts of User Heterogeneity and Attitudinal Factors on Roadway Pricing Analysis: Investigation of Value of Time and Value of Reliability for Managed Lane Facilities in South Florida." PhD diss., Florida International University, 2016.

Kawamura, Kazuya. "Perceived Benefits of Congestion Pricing for Trucks." Transportation Research Record 1833, no. 1 (2003): 59-65. https://doi. org/10.3141/1833-08.

Kawamura, Kazuya. "Perceived Value of Time for Truck Operators." Transportation Research Record 1725, no. 1 (2000): 31-36. https://doi.org/10.3141/1725-05

Korea Development Institute (KDI). A Manual on Cost Benefit Analysis of Highway and Railway, Version 4. 2004.

Korea Transportation Institute (KOTI). Manual for Road Construction Appraisal. 1999.

Kouwenhoven, Marco, Gerard C. de Jong, Paul Koster, Vincent A. C. van den Berg, Erik T. Verhoef, John Bates, and Pim M. J. Warffemius. "New Values of Time and Reliability in Passenger Transport in the Netherlands." Research in Transportation Economics 47 (2014): 37-49. https://doi.org/https://doi.org/10.1016/j. retrec.2014.09.017

Krause, Cory. "A Positive Model of Route Choice Behavior and Value of Time Calculation Using Longitudinal GPS Survey Data." MS thesis, University of Maryland, 2012. 
KRIHS. Value of Personal Travel Time of Toll Road. Korea Research Institute for Human Settlements, 2003.

Lam, Terence C., and Kenneth A. Small. "The Value of Time and Reliability: Measurement from a Value Pricing Experiment." Transportation Research Part E: Logistics and Transportation Review 37, no. 2 (2001): 231-51. https://doi. org/10.1016/S1366-5545(00)00016-8

Lei, Guo. "Value of Time and Marginal Driving Costs for Private Car Drivers with Data from Stockholm Congestion Charging Trial." MS thesis, KTH Royal Institute of Technology, Stockholm, Sweden, 2011.

Levinson, D., and B. Smalkoski. "Value of Time for Commercial Vehicle Operators in Minnesota." TRB International Symposium on Road Pricing. University of Minnesota, 2003.

Li, Zheng, David A. Hensher, and John M. Rose. "Willingness to Pay for Travel Time Reliability in Passenger Transport: A Review and Some New Empirical Evidence." Transportation Research Part E: Logistics and Transportation Review 46, no. 3 (2010): 384-403. https://doi.org/https://doi.org/10.1016/j.tre.2009.12.005

Liu, Henry X., Will Recker, and Anthony Chen. "Uncovering the Contribution of Travel Time Reliability to Dynamic Route Choice Using Real-Time Loop Data." Transportation Research Part A: Policy and Practice 38, no. 6 (2004): 435-53. https://doi.org/https://doi.org/10.1016/j.tra.2004.03.003

Liu, Henry X., Xiaozheng He, and Will Recker. "Estimation of the Time-Dependency of Values of Travel Time and Its Reliability from Loop Detector Data." Transportation Research Part B: Methodological 41, no. 4 (2007): 448-61. https://doi.org/https:// doi.org/10.1016/j.trb.2006.07.002

Meunier, David, and Emile Quinet. "Value of Time Estimations in Cost Benefit Analysis: The French Experience." Transportation Research Procedia 8 (2015): 62-71. https://doi.org/10.1016/j.trpro.2015.06.042

Miao, Qing. "Measuring the Value of Time in Highway Freight Transportation." PhD diss., Texas A\&M University, 2014.

ODOT. The Value of Travel-Time: Estimates of the Hourly Value of Time for Vehicles in Oregon. Oregon Department of Transportation, Policy \& Economic Analysis Unit, 2004.

Puckett, Sean M., David A. Hensher, John M. Rose, and Andrew Collins. "Design and Development of a Stated Choice Experiment for Interdependent Agents: Accounting for Interactions between Buyers and Sellers of Urban Freight Services." Transportation 34, no. 4 (2007): 429-51. https://doi.org/10.1007/ s11116-007-9114-z 
Sheikh, Adnan, Angshuman Guin, and Randall Guensler. "Value of Travel Time Savings: Evidence from I-85 Express Lanes in Atlanta, Georgia." Transportation Research Record 2470, no. 1 (2014): 161-68. https://doi.org/10.3141/2470-17

Smalkoski, Brian, and David Levinson. "Value of Time for Commercial Vehicle Operators in Minnesota." Journal of the Transportation Research Forum 44, no. 1 (2005): 89-102.

Small, K. A, Noland, R., Chu, X., Lewis, D. Valuation of Travel-Time Savings and Predictability in Congested Conditions for Highway User-Cost Estimation, NCHRP Report No. 431 (1999).

Small, Kenneth A., Clifford Winston, and Jia Yan. "Uncovering the Distribution of Motorists' Preferences for Travel Time and Reliability." Econometrica 73, no. 4 (2005): 1367-82. https://doi.org/10.1111/j.1468-0262.2005.00619.x

Sun, Yichen, Tomer Toledo, Katherine Rosa, Moshe E. Ben-Akiva, Kate Flanagan, Ricardo Sanchez, and Erika Spissu. "Route Choice Characteristics for Truckers." Transportation Research Record: Journal of the Transportation Research Board 2354 (2013): 115-121. DOI: 10.3141/2354-12

Tilahun, Nebiyou and Levinson, David Matthew. "Value of Time Comparisons in the Presence of Unexpected Delay." Travel Demand Management and Road User Pricing: Success, Failure and Feasibility. Wafaa Saleh \& Gerd Sammer (eds.), pp. 173-184, Ashgate Publishers, 2009; Available at SSRN: https://ssrn.com/ abstract $=1736028$.

Wang, Zun. "Truck GPS Data in Freight Planning: Methodologies and Applications for Measurement and Forecasting." PhD diss., University of Washington, 2014.

Wolff, Hendrik. "Value of Time: Speeding Behavior and Gasoline Prices." Journal of Environmental Economics and Management 67, no. 1 (2014): 71-88. https://doi. org/10.1016/j.jeem.2013.11.002

Zamparini, Luca, and Aura Reggiani. "Freight Transport and the Value of Travel Time Savings: A Meta-Analysis of Empirical Studies." Transport Reviews 27, no. 5 (2007): 621-36. https://doi.org/10.1080/01441640701322834 


\section{ABOUT THE AUTHORS}

\section{JOSEPH J. KIM}

Dr. Joseph J. Kim, PE. (PI) is Professor at the Department of Civil Engineering and Construction Engineering Management at California State University Long Beach. He supervised two undergraduate students and was responsible for overall project coordination, assuring successful project completion, and preparing the final MTI report. Prior to this research, Dr. Kim played an important role in a research project that evaluated several ITS-based treatments for the safety of a pedestrian crossing the streets funded by the Federal Highway Administration. He worked on the overall management of that project, which included the supervision of students collecting data based on either human or video observation, organization of data, statistical analysis using non-parametric tests, and reporting of the results. The outcomes had been featured in several publications and presentations at the meetings of the Transportation Research Record: Journal of the Transportation Research Board and the annual Transportation Research Board. The PI has previous experience as a GIS specialist at the Gainesville Police Department in Florida and has a minor in statistics, which is a significant advantage for conducting this research.

\section{SAMUEL DOMINGUEZ}

Samuel Dominguez is a senior civil engineering student at the Department of Civil Engineering and Construction Engineering Management at California State University Long Beach who contributed to accomplishing the goals of this research project. His interests within the field include structural engineering and project management. The scope of his work includes assistance of design for the stated preference survey form, collection and analysis of field data with the PI, and preparation of the MTI report.

\section{LUIS DIAZ}

Luis Diaz is a civil engineering graduate with his E.I.T. and is pursuing his MS degree in Civil Engineering at the Department of Civil Engineering and Construction Engineering Management at California State University Long Beach. He is interested in helping the community by finding solutions that will improve the transportation system. He worked on this project to accomplish the goals of this research project. The scope of his work included conducting a supplemental literature review and assisting with design for the stated preference survey form. 


\section{PEER REVIEW}

San José State University, of the California State University system, and the Mineta Transportation Institute (MTI) Board of Trustees have agreed upon a peer review process required for all research published by MTI. The purpose of the review process is to ensure that the results presented are based upon a professionally acceptable research protocol. 


\section{MTI BOARD OF TRUSTEES}

Founder, Honorable

Norman Mineta*

Secretary (ret.),

US Department of Transportation

\section{Chair,}

Abbas Mohaddes

President \& $\mathrm{COO}$

Econolite Group Inc.

\section{Vice Chair,}

\section{Will Kempton}

Executive Director

Sacramento Transportation Authority

\section{Executive Director,}

Karen Philbrick, PhD*

Mineta Transportation Institute

San José State University

\section{Winsome Bowen}

Chief Regional Transportation

Strategy

Facebook

\section{David Castagnetti}

\section{Co-Founder}

Mehlman Castagnetti

Rosen \& Thomas

\section{Maria Cino}

Vice President

America \& U.S. Government

Relations Hewlett-Packard Enterprise

\author{
Grace Crunican** \\ Owner \\ Crunican LLC
}

\section{Donna DeMartino \\ Managing Director \\ Los Angeles-San Diego-San Luis \\ Obispo Rail Corridor Agency}

\section{Nuria Fernandez**}

General Manager \& CEO

Santa Clara Valley

Transportation Authority (VTA)

\section{John Flaherty}

Senior Fellow

Silicon Valley American

Leadership Form

\section{William Flynn * \\ President \& CEO \\ Amtrak}

\section{Rose Guilbault}

Board Member

Peninsula Corridor

Joint Powers Board

Ian Jefferies*

President \& CEO

Association of American Railroads
Diane Woodend Jones

Principal \& Chair of Board

Lea + Elliott, Inc.

David S. Kim*

Secretary

California State Transportation

Agency (CALSTA)

\section{Therese McMillan}

Executive Director

Metropolitan Transportation

Commission (MTC)

\section{Bradley Mims}

President \& CEO

Conference of Minority

Transportation Officials (COMTO)

Jeff Morales

Managing Principal

InfraStrategies, LLC

Dan Moshavi, PhD*

Dean, Lucas College and

Graduate School of Business

San José State University

Toks Omishakin*

Director

California Department of

Transportation (Caltrans)
Takayoshi Oshima

Chairman \& CEO

Allied Telesis, Inc.

Paul Skoutelas*

President \& CEO

American Public Transportation

Association (APTA)

Beverley Swaim-Staley

President

Union Station Redevelopment

Corporation

Jim Tymon*

Executive Director

American Association of

State Highway and Transportation

Officials (AASHTO)

\section{Larry Willis*}

President

Transportation Trades

Dept.,AFL-CIO

$*$ = Ex-Officio

$* *=$ Past Chair, Board of Trustees

\section{Directors}

\section{Karen Philbrick, PhD}

Executive Director

\section{Hilary Nixon, PhD}

Deputy Executive Director

\section{Asha Weinstein Agrawal, PhD}

\section{Education Director}

National Transportation Finance

Center Director

\section{Brian Michael Jenkins}

National Transportation Security

Center Director

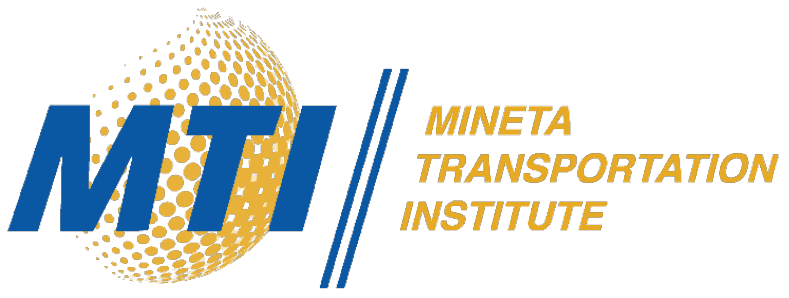

